\title{
EL PODER PENAL DEL ESTADO Y EL NUEVO PROCESO PENAL
}

\author{
Carlos A. Chiara Díaz* y Enzo Finocchiaro**
}

\section{Introducción}

Si bien el nuevo proceso penal necesitaría de una transformación profunda de todo el sistema penal que comenzara con la renovadora y armonización del vetusto Código Penal y de las leyes penales complementarias, conforme se hizo en el proyecto confeccionado durante los años 2005 y 2006 por una comisión de diez juristas convocados por el Poder Ejecutivo Nacional, las provincias han seguido avanzando, tanto que han actualizado sus constituciones y códigos en beneficio de los ciudadanos, lo cual nos parece ponderable y adecuado al régimen federal que nos rige.

Precisamente en este trabajo encaramos el análisis de algunos institutos principales de los nuevos códigos, que se han estructurado conforme al sistema acusatorio, a la mayor participación de las víctimas que pueden constituirse como querellantes o accionantes civiles, inclinándose asimismo por incluir a los ciudadanos en los tribunales de justicia, aunque sea por ciertos delitos seleccionados, lo cual marca una orientación ideológica irreversible conforme a la Constitución Nacional y los tratados internacionales.

\section{Los actores en el proceso penal}

Un sujeto o actor del proceso es aquella persona que forma parte del mismo, ya sea en forma esencial o necesaria, o tangencial o eventualmente. Esa persona puede estar facultada a actuar en el proceso, en alguna parte de este $\mathrm{u}$ obligada a hacerlo. Claro está que, según el modelo al que refiera ese proceso

* $\quad$ Doctor en Ciencias Jurídicas y Sociales, (Universidad Nacional del Litoral). Miembro del Superior Tribunl de Justicia de Entre Ríos. Profesor titular de Derecho Público y Derecho Procesal Penal en las Universidades de Entre Ríos, del Litoral y UCA - Paraná.

** Abogado, especialista en Derecho Penal (UBA), docente (UBA y UB) y colaborador de las revistas jurídicas El Dial y La Ley. 
penal en particular y según la orientación del mismo, la cantidad y calidad de los sujetos procesales variará. En nuestro caso, tomando como partida el proceso penal establecido constitucionalmente, esto es, el proceso penal adversarial acusatorio, podemos distinguir, en una simple categorización académica, entre sujetos necesarios y sujetos tangenciales del proceso penal. ${ }^{1}$

Como bien señalara ya el Maestro Clariá Olmedo,

no son sujetos las personas que intervienen, o solo como colaboradores del tribunal y de las partes ayudándolos, integrándolos o representándolos, o como terceros no ligados directamente al objeto procesal. Así, el concepto de sujeto procesal del rito penal está circunscripto a las personas que actúan en el proceso penal conforme a las atribuciones y sujeciones que les asigna la ley para hacer valer, oponer o satisfacer directamente las pretensiones fundamentadas en el objeto procesal. En todo caso debe tratarse de la pretensión penal, y eventualmente en lo civil; pero no puede dejar de ser inmediata la vinculación con el hecho imputado y con la actuación del derecho en lo que a ese hecho respecta. Asimismo, son principales o esenciales todos los sujetos que actúan en vinculación directa con la pretensión penal, aunque también lo hagan con respecto a la pretensión civil (casos del querellante y del imputado). Cuando la cuestión civil ha sido introducida al proceso, el tribunal competente debe ejercer la jurisdicción respecto de ambas pretensiones: la penal y la civil. Si la instancia civil se dirige contra el imputado, éste opondrá sus pretensiones defensivas también respecto de la cuestión civil. ${ }^{2}$

\section{Acusador, tribunal e imputado}

Con las características que ya hemos venido reseñando en este manual, tomamos como punto de partida al proceso penal adversarial iniciado contra persona conocida, el que posee tres sujetos que siempre necesariamente estar presentes en todo proceso penal contra persona conocida: el acusador, el tribunal y el imputado. El acusador será quien detente la acusación, inicie e impulse la persecución penal y

${ }^{1}$ Clariá Olmedo, Jorge A. (2001), Derecho procesal penal, Rubinzal Rulzoni, Santa Fe, T. I, págs. 260 y ss.

${ }^{2}$ Clariá Olmedo, Jorge A., ob. cit., pág. 267. 
procure obtener, mediante la exhibición de la prueba recolectada en el marco de un juicio, una sentencia condenatoria; el tribunal será quien dirija el proceso, controle la legalidad del mismo y vele por el adecuado cumplimiento de las garantías que el ordenamiento constitucional y ese orden ritual específico prevean para con todas las partes y sujetos del proceso; el Imputado será aquel contra quien se dirija la acusación y quien, merced a un adecuado ejercicio de su derecho de defensa, pueda refutar la persecución iniciada en su contra, presentando pruebas y contra examinando la prueba de la contraparte, es decir, el acusador.

Loa tres sujetos de este acápite son esenciales para la continuidad del proceso. La ausencia de cualquiera de ellos afecta la existencia válida del proceso por defecto en los presupuestos procesales: sin la intervención de un tribunal, de un acusador y de un imputado no se podrá dictar válidamente resolución sobre el fondo en lo principal. Claro está que no debe pensarse en una investigación preparatoria sin autor conocido -momentáneamente- ya que ella no llega a la instancia nuclear del proceso penal -lo que se conoce como “investigaciones N.N.”- esto es, el juicio, que es en donde se "presentan” los actores, principales y secundarios, a hacer valer sus roles.

A modo de resumen, decimos que el tribunal, en cuanto manifestación del órgano jurisdiccional y personificado en el juez o jueces del tribunal oral, es el sujeto principal que tiene a su cargo el ejercicio de la jurisdicción, controlando la legalidad y buen discurrir del proceso, dictando resoluciones provisionales y definitivas sobre las cuestiones que le someten los demás sujetos del proceso y principalmente, dictando la sentencia -condenatoria o absolutoria- que pone fin al proceso, o dictando la extinción del mismo por la causal que sea, respecto del ordenamiento procesal que se trate.

Asimismo, el Ministerio Público Fiscal, o conjunto de los fiscales, es el sujeto público principal que necesariamente y por imperio de la ley hace valer la pretensión penal; es el acusador público de actuación inevitable en el sistema de acusación oficial, una de las dos partes esenciales del proceso adversarial, quien decide sobre la forma que tomará la acción penal y quien toma sobre sus espaldas la confianza que los ciudadanos han depositado sobre el Estado a través del sistema de justicia que prevé una República democrática.

Finalmente, el imputado es la persona que efectiva y necesariamente se introduce como sujeto principal del proceso, por dirigirse en su contra la pretensión penal y eventualmente también puede dirigirse en su contra la pretensión civil. Ejerce el derecho de defensa que la constitución le acuerda, haciendo valer la pretensión de rechazo de la imputación, ofreciendo la prueba que considere 
necesario y rebatiendo los argumentos del fiscal y, eventualmente, del querellante constituido como tal. Por enfrentarse a un proceso letrado, contra un adversario letrado, es condición necesaria y principal que cuente con un adecuado servicio de defensa, ya sea a través de un defensor de su confianza o "defensor particular" o a través de un defensor conferido por el Estado, denominado "defensor público”. En muchos procesos de nuestro país, el Ministerio Público de la Defensa también es considerado un sujeto principal del proceso por cuanto sin su presencia, el proceso adversarial no será equilibrado y perjudicará al imputado, alterando el espíritu de la garantía constitucional del debido proceso.

\section{La víctima}

Inicialmente -en el antiguo derecho germánico-, la víctima ocupaba un lugar central, cuando en el sistema penal los conflictos se resolvían a través de composiciones, como forma común de solución, y el sistema acusatorio era de corte privado. ${ }^{3}$ Luego, la Inquisición la desalojó de ese lugar nuclear, le expropió las facultades y se las dio a la esfera pública, no importando ya la reparación de lo sucedido a aquella, sino centrándose en el menoscabo al sistema estatal e implantando el concepto de "pena estatal" como mecanismo de control de los súbditos. Como bien dice Maier, la víctima pasó a ser un "convidado de piedra del sistema penal”. ${ }^{4}$ De hecho, al imputado también se lo desplazó de su rol protagónico y pasó a ser el objeto de la investigación penal, antes que el propio delito.

Dentro de aquel escenario, hizo su aparición la Victimología, una corriente novedosa, surgida en los años cuarenta, de la mano de autores como Von Hentig ${ }^{5}$ o Mendelsohn, ${ }^{6}$ que se ocupaba de estudiar el rol de la víctima en los

${ }^{3}$ Maier, Julio B. J. (2002), Derecho procesal penal. I. Fundamentos, Del Puerto, Buenos Aires, págs. 264 y ss.

${ }^{4}$ Maier, Julio B. J. (2002), Derecho procesal penal. II. Sujetos procesales”, Del Puerto, Buenos Aires, págs. 582 y ss.

${ }^{5}$ Se trataba de un ciudadano alemán, expulsado de su país por el gobierno nazi y exiliado en los EEUU, donde comenzó a desarrollar un concepto dinámico y multidisciplinario de la víctima, en su trabajo "Renard on the interaction of perpetrator and victim", de 1941, publicado en el Journal of crimnal law and criminology, págs. 303-309. En su posterior "The criminal and his victim" (1948), profundizó y evolucionó este enfoque.

${ }^{6}$ Es quien acuñó el término “victimology”, en contraposición al término criminology, por entender que en lo delitos concurren ambos factores, los derivados del delincuente y los derivados de la víctima. Es autor de “victimology” (1946). 
hechos penales, abarcando distintas disciplinas, tales como la criminología, la psicología social, la sociología, la etnografía, el derecho penal, etc. En la celebración del I Simposio Internacional de Victimología de Jerusalén, en 1973, podemos consensuar la consolidación de esta nueva disciplina como una ciencia. A partir de entonces, comenzó a surgir en los ámbitos académicos la inquietud sobre otorgarle a la víctima un rol más activo en el proceso, y no como un simple espectador. Así, en 1980 se funda la Sociedad Mundial de Victimología, donde se define a la disciplina como el "estudio de los procesos sociales a través de los cuales individuos y grupos sociales son maltratados, con la consiguiente generación de problemas sociales".

A posteriori de esta victimología primigenia, surge una victimología más evolucionada, con un tratamiento específico para darle cabida a la víctima en el ordenamiento procesal penal, pero sin contraponer los derechos del imputado a los de la víctima. Es claro que con una política de “ley y orden”, es más rentable satisfacer víctimas que delincuentes. Aparecen encuestas de victimización, centros de orientación, contención y asistencia de víctimas.

De este modo, conociendo a la víctima, se logra una comprensión integral del cuadro, no debiendo olvidar que el derecho penal no es sino una ciencia social que entra a jugar ante fallas de otros elementos del sistema estatal. Por ello, si la víctima no ha sido abordada con anterioridad, si el derecho penal también le da la espalda, quedará desprotegida.

Así, hoy en día, la mayoría de los códigos procesales penales modernos acuerdan participación, asistencia y contención de la víctima en el marco del proceso penal. Un ejemplo de ello es el Código Procesal Penal de la Ciudad de Buenos Aires, que posee todo un título de su articulado -el Título IV-donde se receptan los derechos de la víctima, tales como recibir un trato digno y respetuoso por parte de las autoridades, restituírsele los gastos causados por el proceso, requerir medidas de protección propia y de sus bienes y grupo familiar y de los testigos que ellos aporten, ser informados de los actos procesales donde participan y a cumplir con los actos procesales, según las circunstancias, en su domicilio. Particularmente, el Art. 38 del CPPCABA prevé:

Derechos de la víctima en particular. Sin perjuicio de lo establecido en el artículo 37- que mencionaba lo dicho anteriormente-, la víctima tendrá derecho: a) A ser informado/a por el/la Fiscal interviniente acerca de las facultades que puede ejercer en el proceso y sus consecuencias; b) A ser informado/a sobre el estado de la causa y la 
situación del/la imputado/a; c) A aportar información durante la investigación; d) A ser acompañado/a por persona de su confianza, cuando sea menor o incapaz, durante los actos procesales en los cuales intervenga, siempre que ello no coloque en peligro el interés de obtener la verdad de lo ocurrido; e) A ser informado/a de los resultados del procedimiento, aún cuando no haya intervenido en él; f) A requerir la revisión del archivo dispuesto por el/la fiscal, aún cuando no haya intervenido en el procedimiento como querellante, en los casos previstos por este Código y a ser notificado/a de las resoluciones que pueda requerir su revisión. ${ }^{7}$

Indudablemente, estamos ante una norma de avanzada, que ha receptado el modelo del Código Procesal Penal Modelo para Iberoamérica de 1988, confeccionado por el Instituto Iberoamericano de Derecho Procesal e inspirado y apoyado en el Código de Córdoba (Argentina), así como las leyes procesales de Francia, Italia, España, y la Ordenanza Procesal Penal de Alemania Federal entre algunas declaraciones, pactos y convenios internacionales. Todas estas normas tienen la fuerte impronta del querido e ilustrísimo Julio Maier.

\section{El querellante}

Un sujeto especial ya mencionado es el mal llamado "acusador privado" o querellante particular, que es aquel que, acreditando una afectación directa y especial por el hecho bajo análisis y cumpliendo determinados requisitos previstos en la ley, puede impulsar la acción penal, ofrecer prueba, solicitar medidas, recurrir resoluciones que considere contrarias y activar todos los procedimientos que la ley pueda atribuirle.

${ }^{7}$ En Argentina, la preocupación por la víctima ha tenido una impronta muy fuerte, sobre todo a partir de la reforma constitucional de 1994. En la actualidad, casi todos los códigos procesales penales tienen previsiones con respecto a la víctima y asimismo las provincias poseen varias agencias estatales dedicadas a la atención de la víctima. En este campo, fue señera la corte suprema de justicia de la nación, estableciendo la oficina de violencia doméstica, que funciona sobre la calle Lavalle y que contara con el gran apoyo de la dra. Elena Highton de Nolasco, quien a su vez recorre el país inaugurando nuevos lugares de atención a víctimas, en especial a víctimas de violencia de género. 
Durante años se debatió, tanto a nivel comparado como a nivel local, si el querellante o acusador privado podía llegar a suplir al fiscal cuando este decidía no acusar o continuar con la acción. Al respecto, nuestro más Alto Tribunal, en el precedente "Tarifeño", 8 sostuvo que la acusación es una de las etapas básicas del proceso penal, por lo que no resultaba válida una condena que se dicte en ausencia de acusación. Así, se anuló una condena, pese que el Fiscal de juicio había pedido la absolución en el debate. ${ }^{9}$

Posteriormente, en 1996, y con una integración diferente, la Corte Suprema comenzó a mostrar disidencias al respecto. Un ejemplo es el precedente “Cáseres, Martín H.”, donde una mayoría (dres. Belluscio, Boggiano, Bossert y Fayt) mantuvieron el criterio de "Tarifeño” y una minoría (dres. Nazareno, Moliné O'Connor -quien había votado en sentido contrario en los precedentes anteriores- y Vázquez), consideró que era posible arribar a una sentencia condenatoria, aun cuando el fiscal de juicio solicite una absolución, pues entendían que el recaudo de la "acusación” estaba ya cumplido con el requerimiento fiscal de elevación a juicio oral.

Así las cosas, en el año 2002 se revisó el criterio de “Tarifeño” en el precedente "Marcilese” ${ }^{10}$. La mayoría (dres. Nazareno, Vázquez, López y Moliné), sumado al voto del Dr. Fayt, sostuvo que era válida la condena sin acusación fiscal, en tanto y en cuanto hubiera existido un requerimiento de juicio. Como se observa, este tipo de razonamientos coyunturales, solo alteran momentáneamente la escena, hasta que nuevamente se retoma la senda correcta, y ello ocurrió en 2004 con el precedente "Mostaccio", ${ }^{11}$ volviendo a la tesitura de “Tarifeño", en la cual los jueces no pueden dictar sentencia de condena en ausencia de una acusación. En la actualidad, esta línea sigue plenamente vigente. ${ }^{12}$

Aquí la cuestión es clara: Al estar deslindadas la función de acusar, de la función de sentenciar, es claro que ni el fiscal puede asumir facultades o roles del Juez, ni el juez puede convertirse en fiscal. Hacer parecer a una pieza como

${ }^{8}$ LL, 1995-b-32.

${ }^{9}$ Carrio, Alejandro (2005), Garantías constitucionales del proceso penal, Hammurabi, Buenos Aires, págs. 80 y ss.

${ }^{10} \mathrm{LL}, 1998-\mathrm{b}-386$.

${ }^{11}$ Fallos 327:120.

${ }^{12}$ Como por ejemplo en Fallos: 327:3087. 
un requerimiento de elevación, propio de la etapa previa, de la etapa preparatoria al juicio, como una pieza de este, para así poder suplir la voluntad absolutoria del fiscal de juicio, es irrogarse el tribunal facultades que el proceso penal, apoyado en la Constitución Nacional, no le confiere. ${ }^{13}$

Ahora bien, como hemos dicho, no solo el fiscal surge como sujeto con potestad de impulso de acción. En algunos artículos y en la vaga letra de algunos ordenamientos rituales se sugiere que el querellante puede convertirse en acusador, y de esta forma, surge la clara pregunta de si puede suplir al fiscal en la acusación, cuando este decida no continuar, impulsar o peticionar la absolución. En nuestra opinión, dado que al fiscal se le asigna la función de detentar la acción penal pública, difícilmente alguien pueda venir a sustituirlo, sea un Juez, sea un querellante, sea quien sea. La Corte Suprema, pese a lo que hemos dicho, no lo ha entendido así en algunas oportunidades.

En el precedente "Santillán”, ${ }^{14}$ la Corte tuvo la oportunidad de reevaluar esta posición. En el caso concreto, se había dispuesto la absolución del imputado por parte del Tribunal Oral, el cual se basó en la falta de acusación del fiscal al final del debate oral, por el contrario, la parte querellante no estuvo de acuerdo con el pronunciamiento y apeló el fallo a la Cámara de Casación, la que confirmó la sentencia absolutoria, argumentando -atinadamente a nuestro entender-que en el proceso penal nacional vigente, el querellante no posee autonomía acusatoria para intervenir en el proceso penal, estando supeditada su actuación a la intervención del titular de la acción penal, esto es, el Ministerio Público. La Corte, equivocadamente según nuestra óptica anteriormente señalada, anuló el fallo recurrido, sosteniendo que aquí no ocurría la hipótesis jurídica de “Tarifeño”, sino que sí existía una acusación al final del juicio y que asimismo negarle a la querella la posibilidad de una sentencia, es proscribir su derecho a la jurisdicción, contenido en el art. 18 de la Carta Magna. Dado que el criterio tomado "Santillán”, a la fecha, no ha sido expresamente revocado por el Alto Tribunal en su nueva conformación, tácitamente se entiende que esa sigue siendo la opinión de la Corte. Debe señalarse que, no obstante lo dicho en "Santillán", algunos criterios sentados en tribunales inferiores, como por ejemplo lo dicho por el dr. Yacobucci en el precedente "Storchi”, de la Sala II de la

${ }^{13}$ Sobre el particular, ver el excelente trabajo de De Luca, Javier Augusto y Manriquez, Gloria (1995), “Condenas sin acusación”, en LL-1995-b-801.

${ }^{14} L L, 1998-\mathrm{e}-432$. 
Cámara Nacional de Casación Penal, rechazan esta postura y niegan a la querella la posibilidad de actuar en forma autónoma, pues las funciones del Fiscal son indelegables en los particulares; más adelante, citaremos esta opinión.

Es necesario mencionar que en algunos procedimientos penales locales, el querellante puede continuar con la acción penal, aunque el fiscal desista, en determinados casos. Así, por ejemplo, el Art. 10 del Código Procesal Penal de la Ciudad de Buenos Aires, dice:

En los delitos de acción pública, la querella podrá continuar con el ejercicio de la acción bajo las formalidades de los de acción privada cuando el Ministerio Público Fiscal hubiera desistido por alguna de las causales previstas en este Código. ${ }^{15}$

Así como el de la ciudad de Buenos Aires, muchos otros códigos procesales penales permiten esta solución, para no privar al querellante del derecho a la jurisdicción, sin dejar de reconocerle al fiscal la titularidad de la acción penal pública, y por ello se hace la salvedad que el querellante podrá continuar con el ejercicio de la acción, pero en la forma prescripta para los delitos de acción privada (art. $73 \mathrm{CP}$ ). Esto ha sido expresamente rechazado por la Cámara Nacional de Casación Penal, en el precedente "Storchi”, donde dijo que

Como consecuencia de lo expresado, la actuación desenvuelta por la querella de manera autónoma al impulso fiscal en esta causa entra en colisión con las previsiones del CPPN y en virtud de ello afecta la garantía del debido proceso y de la defensa en juicio de los imputados Storchi, Giraldi y Bugallo. Conforme los criterios arriba indicados, cabe entonces declarar la nulidad parcial de la apertura del debate impulsado por la querella en relación con los antes nombrados y de las instancias posteriores fundadas en este acto $y$ con ese alcance. En particular también parcialmente, el alegato de aquella parte en la que concretó su imputación personal por el delito de homicidio doloso respecto de los mencionados y la condena impuesta por el a quo -por el delito de homicidio imprudente- a

${ }^{15}$ Para examinar el proceso penal porteño recomendamos dos obras centrales: Cevasco, Luis Jorge (2009), Derecho procesal penal de la Ciudad Autónoma de Buenos Aires”, Ad Hoc, Buenos Aires; y La Rosa, Mariano y Rizzi, Aníbal (2010), Código procesal penal de la Ciudad Autónoma de Buenos Aires”, HYS, Buenos Aires. 
Storchi y Giraldi -Bugallo fue absuelto. Como consecuencia de ello habrá de absolverse a Storchi y Giraldi - por falta de requerimiento de elevación a juicio del fiscal (arts.167, inc.2, 172, 346, 374, 393 y concordantes del CPPN y art.18 de la CN)... En consecuencia, mientras en el precedente "Santillán» esa acusación con la que se abre el debate fue concretada por el Ministerio Público, en el proceso ahora analizado no ha existido ese acto esencial que recae en la competencia del acusador público. La querella, como quedara expuesto, no puede en virtud de la normativa ordinaria, impulsar por si sola -autónomamente- el inicio del juicio. Por el contrario, la Corte le ha reconocido en los términos ya vistos, la legitimación para que de manera relativamente autónoma «cierre» la imputación personal con prescindencia de la última opinión fiscal. No es este el supuesto que motivara los agravios de las defensas y por lo tanto la doctrina del caso «Santillán» no es de aplicación al caso ya que carece de analogía en términos normativos con ese precedente. (Del voto en disidencia parcial del dr. Yacobucci) ${ }^{16}$

En la misma tesitura, la Cámara Nacional de Apelaciones en lo Correccional y Criminal de la Capital Federal, sostuvo que

toda vez que el ministerio público, único órgano facultado para promover la acción penal en los delitos como el que aquí se investiga, ha propiciado la desestimación de las presentes actuaciones por inexistencia de delito; no resulta posible sustanciar el recurso interpuesto por el pretenso acusador particular. Así, 230 entonces, como en este caso la acción no ha sido legalmente promovida, no existe proceso penal; el cual no puede tener inicio por única iniciativa de la querella o quien pretende serlo, por vía de una apelación. (1) (....) una correcta interpretación de las normas vigentes, permite sostener que la facultad acordada al querellante -o pretenso acusador-, de apelar la desestimación o archivo de las actuaciones (y de este modo impulsar la investigación), solo se reduce a aquellos supuestos en que, o

${ }^{16}$ CNCP - Sala II - 15/07/2010, Causa N 8361. «Storchi, Fernando Martín y otros s/ recurso de casación». Se observa que la opinión anotada es una disidencia y no la opinión mayoritaria de la Sala II del tribunal. 
bien previamente ha sido legalmente promovida la acción, o bien que dicha decisión jurisdiccional haya sido tomada como consecuencia del rechazo, por parte del juez, del requerimiento de instrucción (art. 195 del C.P.P.N.). A esos casos se refiere el art. 180 in fine del código de forma cuando lo faculta a apelar y, en definitiva, a impulsar (art. 82 del C.P.P.N.)». Estas decisiones fueron anuladas por la Cámara Nacional de Casación Penal, ya que las distintas salas coincidieron en otorgar legitimación al pretenso querellante para interponer recurso de apelación, con base en el plenario "Zichy Thyssen», en el que, al decidir si el pretenso querellante se encuentra legitimado para interponer recursos de casación - cuestión que el voto mayoritario resolvió afirmativamente-; los camaristas votaron afirmativamente. De ello se infiere que el superior también le otorga capacidad para interponer el recurso de apelación. ${ }^{17}$

Como resumen, queda claro que el querellante es un sujeto particular y eventual del proceso, que se introduce en el proceso penal pretendiendo hacer valer contra quien resulta imputado por el fiscal en un hecho concreto, haciendo valer su pretensión surgida del mismo hecho contenido en la imputación hecha por el titular de la acción penal, esto es, el fiscal, a cuyo actuar está supeditado y al que no puede sustituir, salvo que la ley ritual le acuerde la posibilidad de sucederlo si aquel desiste.

\section{El actor civil}

El ilícito civil puede o no ser delito penal; en cambio de acontecer este último necesariamente existirá ilícito civil en la medida que provoque daño (art. 1067, Cód. Civil); en este caso, el afectado tiene dos opciones: a) ejercer la acción civil en el Fuero Civil, aunque condicionada por el resultado previo de la (arts. 1101, 1102 y 1103, Cód. Civil) o b) ejercitar la acción civil en forma dependiente de la acción penal pública, ocasionando una acumulación de acciones.

Así las cosas, el actor civil, que se presenta en el proceso penal, es el sujeto damnificado por el hecho afirmado en la acción penal pública, que hace Luis".

${ }^{17}$ CnCrim y Correc - Sala V - 17/09/2009, Causa No 37.525 - "Tavolaro Ortiz, Eduardo 
valer una pretensión resarcitoria privada -acción civil- contra el imputado y en su caso contra el tercero civilmente responsable (que es aquel quien asumió el rol de garante respecto de los actos del imputado en el caso concreto).

No es suficiente afirmar la existencia de un daño, sino que asimismo se requiere la constitución, en la mayoría de los procesos penal, en actor civil, carga procesal exigida para luego ser considerado como sujeto -secundario- del proceso.

Generalmente, el actor civil accede al proceso penal sin ejercer propiamente la acción civil, lo que recién hará tiempo más tarde al introducir su demanda, en el Tribunal respectivo. Además, la constitución en actor civil es condición de admisibilidad de la ulterior demanda, porque para ejercer en el proceso penal la acción civil emergente del delito, su titular debe previa y necesariamente constituirse en actor civil.

\section{El civilmente demandado}

Como ya dijéramos, el tercero civilmente demandado es el sujeto particular y accesorio que por citación o espontáneamente se introduce en el proceso penal cuando se ejerce en él la acción civil, por afirmarse que conforme al derecho privado ha de responder por el daño causado con el delito que se atribuye al imputado, en cumplimiento de lo que conocemos como el "rol o posición de garantía".

\section{Acción procesal penal: principio de legalidad y oportunidad}

En primer lugar, es necesario distinguir los conceptos de ejercicio de la acción con la función de jurisdicción en el marco de un proceso adversarial acusatorio. Anteriormente, en los sistemas inquisitivos, ambas funciones se concentraban en el Juez, por lo que la distinción era meramente doctrinaria o académica; hoy en día, esto ya no es así y quien juzga y quien acusa son sujetos procesales distintos.

Por imperativo republicano y constitucional, quien monopoliza la capacidad de decidir el derecho aplicable a situaciones sometidas a escrutinio, esto es, la jurisdicción, es el Estado, pues entre las funciones que los propios ciudadanos han delegado en este a través del contrato social, está la de decidir respecto de conflictos o de situaciones problemático-jurídicas sometidas a él. Concreta- 
mente, nosotros nos referiremos al campo de los conflictos con normas de tipo penal o civil con incidencia penal. En la división republicana que establece nuestra Constitución, esa función de decidir el derecho aplicable -la función de juzgara determinado caso, recae en el Poder Judicial. Así, en cuanto ente soberano, el Estado es el titular de la jurisdicción, a través del poder judicial. Entre nosotros, lo son tanto el Estado nacional como el de cada provincia, que tienen su respectivo órgano jurisdiccional. No son jurisdiccionales los llamados tribunales de policía o municipales, por lo cual se viola la garantía judicial cuando sus decisiones condenatorias no son revisadas con juicio previo por un tribunal penal, ni asimismo los entonces denominados “jueces de la Ley”, en la Capital Federal. ${ }^{18}$ Solo puede haber jueces de la Constitución.

Ahora bien, esa jurisdicción o potestad de brindar justicia (penal) por parte del Estado, debe ponerse en marcha de alguna forma. Esa forma en la que dicha jurisdicción se excita, se denomina "ejercicio de la acción penal (del Estado)". Recapitulando y previo a todo, decimos que en el modelo moderno de esquema adversarial acusatorio se diferencian nítidamente las funciones de investigar, requerir y decidir y los poderes de acción y de jurisdicción.

Aunque la forma en cómo se ejercita la acción penal es una cuestión netamente procesal, el legislador nacional la positivizó en el ordenamiento de fondo, lo que a nuestro entender constituye una deformación de la técnica legislativa, y lo que se justificó entonces como un intento de uniformar criterios e "imponerle” a las provincias el cómo se debe ejercitar dicha acción penal, lo que también resulta errado e incluso más grave, pues constituiría una violación a las autonomías provinciales (si dejo que la provincia regule el proceso, cómo no permitirle que decida cómo se inicia dicho proceso o cómo finaliza). Algo de esto es lo que han tenido en cuenta algunos legisladores provinciales y que luego veremos.

El llamado "problema de la acción"19 ha sido una de las cuestiones más debatidas durante los pasados doscientos cincuenta años, desde la Revolución Francesa de 1789 en adelante, cuando se impuso el llamado "modelo de la legalidad", un modelo eminentemente normativo donde el poder legislativo asume un rol central, elaborando las leyes que serán el instrumento de control social por excelencia. Posteriormente, los Códigos de Napoleón reforzaron y

${ }^{18}$ Fallos: 30:112.

${ }^{19}$ Binder, Alberto (2009), Introducción al derecho procesal penal (2a ed.), Ad-Hoc, Buenos Aires, pág. 209. 
renovaron los fundamentos normativos del modelo penal y del pensamiento jurídico dominante en sí. Así, en el camino entre la teoría y la realidad, entre los derechos que se plasman en la Constitución y en las normas y los derechos que efectivamente el ciudadano “de a pie” puede ejercer frente al Estado -representado en su poder judicial- la conceptualización de cómo se realiza ese ejercicio tiene un rol protagónico. Estamos frente a lo que Binder llama "la llave maestra del ciudadano". ${ }^{20}$ Ahora bien, a través de la burocratización incesante que ha ido nutriendo al Estado desde entonces, también se ha ido operando una abstracción de la mayoría de los derechos que el ciudadano tiene en desmedro de este, a favor del Estado. Así, el derecho a la salud, el derecho a la educación, el derecho a la elección de autoridades, no se ejercen en forma directa sino en la forma en la que el Estado lo decide (o lo "reglamenta"). El derecho al acceso a la justicia no es distinto de ellos y entonces el concepto de acción penal pública aparece como uno de los elementos fundamentales de soporte de la legitimación del Estado en el proceso penal, ${ }^{21}$ que por otra parte, al asumir y asegurarse las funciones de perseguir y juzgar, monopoliza la "violencia legítima” o fuerza, intentando de este modo reducir los niveles de agresión que la propia conducta delictiva produce y asimismo eliminar o morigerar las venganzas entre particulares o privadas.

La acción penal es, por regla general, de carácter público y oficial; “público”, pues la lleva adelante un órgano del Estado, que como ya dijéramos es el Ministerio Público Fiscal; “oficial” o “de oficio”, pues el órgano público tiene el deber de promoverla y llevarla adelante, sin que pueda abstenerse.

En este sentido, dice el Art. 71 del Código Penal: «deberán iniciarse de oficio todas las acciones penales, con excepción de las siguientes: 1) Las que dependieren de instancia privada, 2) Las acciones privadas».

Así, las excepciones al principio general son:

a) Acciones dependientes de instancia privada, que son acciones públicas que se inician con la condición que la víctima por sí o por su representante legal anoticie al Estado de lo ocurrido, a través del instrumento conocido como "denuncia”, que como sabemos es el acto que pone en marcha el proceso penal. Se dice que «no se procederá a formar

${ }^{20}$ Binder, A., ob. cit., pág. 210.

${ }^{21}$ Binder, ob. cit., pág. 213. 
causa sino por acusación o denuncia del agraviado o de su tutor, guardador o representantes legales». Las acciones dependientes de instancia privada están taxativamente enumeradas en el Código (art. 72) y son aquellas que nacen de los delitos de abuso sexual con o sin acceso carnal (art.119), estupro, rapto y ultraje al pudor, cuando no resultare la muerte de la persona ofendida (art.120), así como lesiones leves (que en realidad, si el fiscal lo considera, la puede transformar en una acción de oficio) y el delito de impedimento de contacto previsto en la Ley 24270, que también, según las circunstancias, puede transformarse en una acción de oficio.

b) Acciones privadas, en las que, si bien también como en las demás figuras se encuentra presente el interés público en perseguirlos, este se ajusta al interés del damnificado, pues se encuentran afectados íntimamente bienes jurídicos, respecto de la que no resulta suficiente que el damnificado manifieste su voluntad de poner en movimiento la acción sino que debe llevarla adelante, como expresión de una permanencia en ese propósito. Las acciones privadas están enumeradas en el art. 73 del CP y son las calumnias e injurias, la violación de secretos (salvo en los casos que esta figura la cometa un empleado de correos o un funcionario público, donde serán acción públicas oficiosas), la concurrencia desleal y el delito de Incumplimiento de los deberes de asistencia familiar, cuando la víctima fuera el cónyuge, previsto en la Ley 13944.

A modo de síntesis entonces, si una conducta tensiona la norma penal, debe promoverse la acción, generalmente por los propios órganos públicos y de oficio, o sea sin requerimiento extraño de un particular o de otro órgano. El ejercicio de la acción exclusivamente por el ofendido o por el órgano estatal condicionado a solicitud del ofendido son excepciones al principio de oficiosidad.

El cómo se promueve y se ejerce la acción, a pesar de lo que diga el Código Penal, debe regularse -y así está hecho- en los códigos procesales, que es donde se establecen las atribuciones y sujeciones del acusador para ese ejercicio y las causas que pueden evitarlo o detenerlo. Sin embargo, surge el debate respecto de la naturaleza penal o procesal de las normas que regulan la acción contenidas en el Código Penal. Es preciso destacar que la mayor parte de la doctrina asigna a dichas normas naturaleza penal. En este sentido se expiden Núñez, Soler, Fontán Balestra, Clariá Olmedo, Maier, entre otros. 
Es un error muy común confundir el ejercicio de la acción penal con el poder punitivo del Estado. Aunque el Estado sea el titular de ambos, no corresponde enrolarnos en la corriente monista que unificaba el derecho con la acción como si esta fuera un ejercicio del poder punitivo estatal. Conforme a estas teorías monistas, denominadas “clásicas”, el mismo poder punitivo "subjetivismo"- o derecho penal -“objetivismo” -sería acción penal cuando entra en movimiento al ser lesionado-. Así, por ejemplo, Carrara definía a la acción penal como la exteriorización del derecho penal sustantivo una vez ocurrida su violación para restablecer su imperio y entonces la acción sería el movimiento del derecho penal que tiende a eliminar la lesión que ha sufrido aplicando la sanción al violador de la norma. En realidad la acción es un poder del Estado distinto al punitivo o diverso del derecho penal sustantivo cuya actuación se persigue en el proceso. Esto nos ubica en las doctrinas autonomistas en cuanto afirman un dualismo entre derecho subjetivo y acción. En lo penal ambos son poderes del Estado que fluyen del orden jurídico integral como dos rayos perfectamente diferenciados por su dirección y contenido.

Así, el poder de acción es autónomo del poder punitivo o norma que da relevancia jurídica penal al fundamento de la pretensión, siendo indiferente la realidad de ese fundamento para la vigencia de la acción. Sin embargo, para que esté realmente vigente como expresión del orden jurídico penal debe presentarse la posibilidad de que haya un sujeto penalmente responsable.

Como ya hemos dicho, no corresponde expedirnos aquí respecto del trámite que se le da a esa acción, pues es harina de otro costal, pero baste decir que la misma se puede iniciar de oficio, esto es, cuando el Ministerio Público Fiscal a través de sí, de otro órgano judicial o de autoridad competente, toma conocimiento de la probable existencia de un delito (la conocida "notitia criminis") de acción pública o mediante denuncia de la víctima, afectado, particular damnificado o de sus representantes legales y pone en marcha el proceso penal.

Como ya hemos dicho en el punto I, quien ejerce la acción penal es el Ministerio Público Fiscal, que podrá ser sucedido, ante la negativa de continuar, por el querellante debidamente constituido, si es que la ley procesal respectiva así lo prevé.

\section{Legalidad versus oportunidad}

En los modernos procesos penales, ante la sobrevivencia de los modelos inquisitivos puros, reformados o mixtos y la pervivencia en ellos del principio de 
legalidad, se hace evidente la tensión entre este y el principio de oportunidad. El primero, respondiendo a las concepciones absolutas de la pena y el segundo respondiendo a las teorías utilitarias propias de las corrientes preventivas. ${ }^{22}$

En lo que al ejercicio de la acción penal respecta, el principio de legalidad no es sino la obligación, sustentada en la Ley, de perseguir todos y cada uno de los delitos de los cuales el Estado tenga debida noticia. Este principio, calificado por Hassemer como «clásico» en nuestro orden cultural, se recuesta más sobre el respaldo que le otorgan las teorías absolutas de la pena (fiat iusticia, pereat muridus) y, por ello, posee un alto grado ético, consecuente con el Estado de derecho. Por ello, sus valores principales residen en la pretensión de igualdad de tratamiento de los habitantes ante la ley, de conservar al máximo la división de poderes, de tornar realidad, en la mayoría de los casos, que la solución del conflicto provenga de un juicio público, inmediato y oral. En definitiva, todas estas razones residen en el ámbito de la equidad ideal de la administración de justicia penal. En respeto a ello, es que el Estado debe perseguir todas las infracciones a las normas y dejar de hacerlo significa "endeudarse" con la sociedad que ha puesto su confianza para que ello no ocurra y hace responsables a los funcionarios que omitan dicha persecución o juzgamiento. El principio de legalidad garantiza, para la fundamental aplicación de la justicia penal, que se dará un trato igualitario a los ciudadanos y ello obliga a la aplicación igualitaria de las normas penales. Las normas penales tienen validez con plena independencia del aspecto o del prestigio de la persona -debe recordarse que el símbolo de la justicia es la venda que cubre los ojos no distinguiendo frente a quien se posiciona-. No se puede, en virtud de este principio, exceptuar, que el poder político, financiero o personal determine de alguna manera la aplicación de las normas penales y con ello se lesione el precepto de igualdad de trato para todos los ciudadanos, constitucionalmente previsto. ${ }^{23}$

Entonces, sea que se afirme la naturaleza penal de las normas incluidas en el Código Penal que regulan la acción, sea que se sostenga su carácter procesal, debe preservarse en esta cuestión la unidad de ordenamiento jurídico. Al respecto, una gran parte de la doctrina defiende el hecho que el Código Penal regule lo concerniente a las condiciones de ejercicio de la

${ }^{22}$ Hassemer, Winfried (1988), “La persecución penal: legalidad y oportunidad”, en jueces para la democracia, $\mathrm{N}^{\circ} 4$, Unigraf S.A., Madrid, pág. 8.

${ }^{23}$ Hassemer, W., ob., cit., pág. 12. 
acción penal y a sus causas de extinción, por ser el Congreso Nacional el órgano competente para establecer el régimen de la acción en lo que hace a las condiciones para su ejercicio y las causas de extinción y para esta posición, la introducción de criterios de oportunidad para limitar la persecución penal de algunos hechos punibles, formulado por la mayoría de los códigos procesales de corte acusatorio-adversarial, colisiona con definiciones previamente determinadas por la ley nacional, pues el principio general del art. 71 no puede resultar menoscabado por una ley procesal cuyo alcance, en principio, no excede el ámbito local para el cual fue dictada; hasta tanto el legislador no modifique, con extensión general abarcativa de todo el país, esa determinación.

En contraposición al principio de legalidad, que ha venido gobernando nuestros procesos, su inicio y su extinción, desde el referido advenimiento del modelo normativo napoleónico, ha surgido en los últimos años -y se ha consolidado fuertemente- el llamado principio de oportunidad. El principio de oportunidad entonces se transforma en la antítesis del principio de legalidad. Este principio permite la existencia de una facultad del titular de la acción penal pública de abstenerse de su ejercicio o de instar oportunamente ante el órgano jurisdiccional el sobreseimiento de la causa bajo los mismos presupuestos, o directamente y en algunos casos, archivar o reservar las actuaciones por motu propio.

Doctrinariamente, existe un sector que se pronuncia por una apertura al principio de oportunidad, aduciendo que el principio de legalidad, al fundamentarse en el concepto retributivo del proceso, fundado en la teoría absoluta de la pena, da la idea de que impera un orden absolutista. Tal razonamiento resulta inaceptable con el Estado de Derecho y con las funciones correspondientes al moderno Derecho Penal, orientado a las nuevas concepciones de la sanción y basado en la existencia real de un orden relativo y contradictorio.

No obstante, en el Derecho Penal Continental, el principio de legalidad, en el ejercicio de la acción penal y en forma anquilosada, es la norma predominante en el proceso penal. Independientemente de tales dogmas, algunos países de la región, gracias a esfuerzos académicos, acuerdos entre gobiernos y programas de asistencia de ONG's y organismos internacionales (ILANUD, INECyP, CELS, APDH), se han ido asentando en las conciencias legislativas primero, y en los ordenamientos procesales penales después, criterios de Oportunidad Reglada con el objetivo de conquistar una mayor eficiencia y celeridad de la Administración de 
Justicia. ${ }^{24}$ Estos criterios solo son concebidos para el enfrentamiento a hechos típicos de escasa trascendencia que se desarrollan en el marco de la pequeña y mediana criminalidad. Y esto quizás responde a una realidad indiscutible de la actuación judicial en nuestros países: Al ser la justicia -y en especial la penal- el único foro donde el ciudadano pretende encontrar vindictas a sus frustrados reclamos en otras áreas, así como al enorme aumento delincuencial sufrido por la región en los últimos treinta años, no se ha logrado otra cosa que colapsar el sistema judicial con miles de millones de causas, no logrando otorgar respuestas adecuadas a nadie y poniendo en duda si el principio de legalidad, en cuanto obligación a iniciar e investigar todo, sin posibilidad de discernir si el asunto merece un trámite judicial o si puede otorgársele una respuesta más efectiva por otro canal o incluso a través de una solución alternativa (como una mediación prejudicial, por ejemplo). Un caso testigo de parálisis judicial es Argentina, y en particular, la Capital Federal. Al respecto, se ha dicho que

la justicia penal carece de capacidad para lograr el esclarecimiento de los hechos denunciados cuando los autores son desconocidos, así como de medios y estructuras para avanzar en la tramitación de ilícitos complejos, que en algunos casos se eternizan y en otros su resolución, al menos parcial, demora mucho tiempo. Esta situación explica el 8\% de casos aún en trámite, luego de más de cuatro años en la justicia de la Capital Federal, y los extensos tiempos registrados en la demora para la elevación a juicio de los procesos relevados. ${ }^{25}$

${ }^{24}$ Brasil introduce el principio de oportunidad con la Ley 9099 de 1995, donde el ministerio público puede «disponer» de la acción pública que le compete en hipótesis determinadas por ley -es condición la reparación a la víctima-. En determinados delitos de acción pública de escasa entidad, la reparación aceptada por la víctima implica la renuncia a la representación y el archivo de las actuaciones.

${ }^{25}$ Chayer, H.; Garavano, G.; Otamendi, S. y Scotto, M. (2007), "Unidad fiscal de investigación de delitos con autores ignorados: una propuesta de organización”, Buenos Aires, La Ley. Para una análisis más profundo y completo con información empírica de esta cuestión se sugiere ver: “Justicia argentina: crisis y soluciones”, Germán C. Garavano, Iudec - Fores, 1997; “Informe de diagnóstico sobre la justicia penal”, presentación de Germán C. Garavano en las jornada sobre reforma judicial y justicia penal, Fores- Bank Boston, 1998; "El rol disuasivo de la justicia”, por Germán C. Garavano y Santiago Otamendi, en revista colección de la escuela de ciencias políticas de la universidad católica argentina, año 6 - n 10 ; y la presentación del lic. Eugenio Burzaco y del dr. Germán C. Garavano en la II Reunión del Consejo Federal de Política Criminal de los Ministerios Públicos de la R. Argentina, Posadas, junio 2001. 
En torno al tema los que mantienen la posición legalista, sostienen que desde que el legislador criminaliza una conducta no pueden admitirse excepciones a la función requirente de la autoridad competente establecida a esos efectos, que es el Fiscal. Contrariamente y a través de la discrecionalidad que otorgaría el principio de oportunidad, este estaría sustituyéndolo y disponiendo en virtud de una norma procesal, para frenar los esfuerzos legislativos por tipificar conductas y fijar penas. Sustitución esta considerada peligrosa pues además da la posibilidad al ente acusador de adoptar decisiones arbitrarias y discriminatorias en detrimento de la función represiva del estado. También se vulnera, en opinión de este sector, el principio de igualdad al permitirse discriminar a la persona de forma tal que unas conductas sean perseguidas y otras no.

Asimismo algunos legalistas consideran que encegueciéndose con las ventajas del principio de oportunidad, sus partidarios olvidan algunos derechos fundamentales y suponiendo un grave retroceso en el sistema de garantías.

El principio de oportunidad, académicamente hablando, se puede dividir en dos grandes modelos: el sistema de oportunidad amplio, que es el seguido por los países que adoptan el modelo del common law anglosajón. Este sistema está caracterizado porque el Ministerio Fiscal ejerce la acusación luego de negociar con el acusado o su representante legal, sin sujeción a ninguna regla preexistente, a través del conocido "plea bargaining". ${ }^{26}$ Aquí el juez es un ente pasivo que se sustrae al conocimiento de los hechos limitando su papel a la decisión sobre los términos de la negociación. El segundo modelo es el conocido como de "oportunidad reglada” y es propio del Derecho Continental Europeo (España, Francia, Italia, Holanda, Portugal, Alemania), y a sus áreas de influencia como son los Países Latinoamericanos, entre ellos, Argentina. En este último sistema, en particular en varios sistemas procesales penales provinciales, la ley prevé los supuestos sobre los cuales el Ministerio Fiscal puede renunciar a su actividad persecutora y a la acción penal y decidir el archivo de casos que revistan características de delitos.

Hassemer sostiene que cada uno de estos principios contradictorios acentúa partes diferentes de la idea de regulación jurídica. La legalidad se coloca del lado de la justicia ideal, del lado de las teorías absolutas de la pena y es

${ }^{26}$ Hendler, Edmundo (2006), El derecho penal y el derecho procesal penal en los estados unidos”, Ad-Hoc, Buenos Aires. 
respetado como clásico mientras que la oportunidad se inclina hacia la orientación a fines del derecho penal, hacia las teorías relativas de la pena y se le menciona como moderno. De esta manera el mencionado profesor obliga al miramiento y reflexión de la relación legalidad y oportunidad como problema de implementación del derecho antes que un problema teórico. Para ello propone que los casos de oportunidad sean determinados con precisión para resguardar la igualdad y el estado de derecho. Propone además una instancia jurisdiccional que controla las decisiones de los órganos persecutores implementando así la esencia de la víctima como sistema de control, ${ }^{27}$ lo que nos parece medianamente correcto, habida cuenta de la diferencia existente entre el ámbito de enunciación del referido jurista y nuestra realidad judicial-criminal actual.

Es indudable que iniciándose todos los procesos, por las formas expuestas, y teniendo que llevarse todos los procesos hasta un dictado de sentencia absolutoria o condenatoria en juicio, lo único que se logrará, amén de fracasar en ello, será abarrotar los tribunales de papeles, personas y sollozos, desvirtuando el rol para el que se ha pensado la justicia, que es otorgar soluciones a los ciudadanos frente a los conflictos que la sociedad o ellos mismos presentan. Si la única oposición atendible a los criterios de oportunidad radica en que el legislador previó un sistema legalista y el Fiscal no puede modificarlo sobre su discrecionalidad, pues entonces tendremos que repensar la legislación que hemos tomado de otras realidades y adaptarla a la nuestra.

\section{Suspensión del proceso a prueba y otros institutos}

En primer lugar, queremos destacar que no debe confundirse al principio de oportunidad anteriormente mencionado con las soluciones alternativas al proceso, ya que existe un cierto sector doctrinario que pretende ubicar la aplicación del principio de oportunidad como una figura jurídica de solución del conflicto alternativa al juicio y ello es incorrecto, pues el principio de oportunidad lo que supone es la facultad discrecional que tiene el ministerio público de poner o no poner en práctica la persecución penal por falta de interés y por razones de política criminal. En el principio de oportunidad, a diferencia de las soluciones alternativas, no se le exige nada al imputado, por lo que no se trata

\footnotetext{
${ }^{27}$ Hassemer, Winfried, “La persecución penal: legalidad y oportunidad”. Obra contenida en CD - rom de conferencias de la UNJC de Pinar del Río, Cuba. pág. 2.
} 
entonces de una solución que produzca la paz social. Al contrario, lo que sí hay es una revelada falta de importancia de ese conflicto, evidenciada en la poca dañosidad al bien jurídico tutelado que presenta o en la falta de compromiso grave al interés público.

Aquí, lo que trataremos serán aquellas formas que evitan la realización del juicio oral, tanto por la posibilidad de solución del conflicto mediante una conciliación imputado-víctima, como por la posibilidad de, ante la no afectación grave del bien jurídico, evitar el desgaste procesal y judicial que supone llegar hasta un juicio oral, arribando a soluciones más acordes al caso concreto, como ocurre en el caso de la suspensión del juicio a prueba, o del juicio abreviado, entre otros. Estos institutos se vinculan claramente con la ya mencionada necesidad de descomprimir el sistema judicial, agilizarlo, dotarlo de mayor eficacia, apuntar sus armas a los delitos graves, procurando que aquellos delitos de menor cuantía o de índole familiar o vecinal que muchas veces resultan judicializados, tengan una respuesta acorde (por ejemplo, normalmente, en un problema vecinal, lo que se pretende es una no acción del vecino o en una acción, no deseándose una privación de libertad, que sería el fin lógico de avanzar gracias a la férrea luz del principio de legalidad.

Nos centraremos en cuatro institutos, sin perjuicio de que puedan existir otros. Hemos elegido a estos, pues son los más conocidos, los más representativos y los que concentran la mayoría de las soluciones alternativas elegidas por los sujetos del proceso, por no decir su totalidad. Previo a comenzar, es preciso remarcarle al lector que se hará una enunciación somera de los mismos, y que para profundizar, se recomienda seguir la bibliografía que se citará a pie de página.

\section{La suspensión del juicio a prueba}

El antecesor de la suspensión del juicio a prueba, el instituto de la «Probation», encuentra sus orígenes en el common law anglosajón, en el año 1887, en donde se distinguía entre dos conceptos similares pero de diferente aplicación de acuerdo a los momentos procesales en los cuales se instrumenta: la «diversion» y la «probation». La primera se interpone en un momento inicial del proceso y tiende a la desestimación de los cargos efectuados contra una persona. Esta debe cumplir, en un período determinado de prueba, ciertas obligaciones cuyo resultado favorable permite la extinción de la acción 
persecutoria, mientras que, por el contrario, si el resultado es negativo, da lugar al inicio del proceso. ${ }^{28}$

Al respecto y sobre la figura de la "diversion”, Bovino señala que la práctica de la 'diversion' surgió en los últimos años de la década del 60. Desde su modesto comienzo en 1967, el movimiento de los programas de 'diversion' se difundió apoyado generosamente por el financiamiento de fondos federales. A este apoyo económico se sumaba el entusiasmo de las autoridades con una estrategia que prometía desviar casos de los sistemas de administración de justicia, sobrecargados de trabajo y, al mismo tiempo, proporcionar una respuesta rehabilitadora efectiva. Para 1978, casi todos los estados contaban con un programa en una o más jurisdicciones, y muchos de ellos habían sido formalizados mediante la sanción de leyes aplicables a todo el territorio del estado.

Pero en menos de una década, el instituto demostró su fracaso. Por un lado, los programas ejecutados no lograron alcanzar los fines propuestos; por otra parte, la ejecución de los programas terminó por agravar la situación que ellos pretendían resolver. Sin embargo, pese al infructuoso empleo de esta figura, se insistió en su aplicación, fundamentalmente porque quería establecer una alternativa frente al fracaso de la justicia penal para afectar el comportamiento de quienes eran sometidos a ella. ${ }^{29}$

En el derecho anglosajón -más precisamente en EEUU- la probation se interpone durante un proceso en trámite, con la culpabilidad del imputado establecida y con el mero objetivo de evitar la condena privativa de la libertad, así como requiere cumplir ciertas reglas de conducta que contribuyan a la rehabilitación del delincuente, en una postura de clara prevención especial positiva. Si el instituto prospera, se extingue la acción penal, y de ocurrir lo contrario, se reanuda el proceso. Como vemos, la «probation» no es sino una forma de cumplir la pena de cárcel, sustituyéndosela por la obligación de cumplir en libertad

${ }^{28}$ Forgione, Marisa S. (2002), La probation, La Ley, dj, 2002-3, 221.

${ }^{29}$ Bovino, Alberto (1997). "La suspensión del procedimiento en el código penal argentino y la ‘diversion’ estadounidense (un análisis comparativo)», La Ley, 1997-a, 1081. 
ciertas pautas de conducta. ${ }^{30}$ Por ello, no debe confundirse a este instituto con la suspensión del juicio a prueba receptada en el ordenamiento argentino, toda vez que no tienen nada que ver.

En Argentina, la suspensión del juicio a prueba fue introducida por la Ley 24316, ${ }^{31}$ incorporada al Código Penal, a través de los Arts. 76 bis al quáter.

Según nos cuentan Lanaro Ojeda y Sueiro en un precioso trabajo que hemos tomado como base para el presente, a la sanción de la mencionada norma se le dieron diversos fines, los que podemos concentrar en dos grandes corrientes de pensamiento al respecto. La primera de ellas, y quizás las más utilitarista, sostiene que la implementación del instituto responde a la intención de descongestionar el sistema de administración de justicia. La segunda, con un fin mucho más altruista, sostiene que por intermedio de la aplicación de este instituto se evita la estigmatización que implica el proceso penal respecto del justiciable y la eventual imposición de condena, aún en los casos en que esta es de ejecución condicional. ${ }^{32}$

En este sentido, D’Alessio y Divito en su magnífica obra, sostuvieron que respecto de ese doble orden de razones que fundamentan esta institución, se ha explicado que la suspensión del juicio a prueba es una medida alternativa de resolución de conflictos cuyo objetivo subyacente consiste en evitar la estigmatización del imputado, buscando además simplificar el tratamiento de algunos asuntos penales como consecuencia de la imposibilidad práctica del sistema para abarcar todos los casos que existen. En esa misma línea, se resaltó que la probation persigue lograr mayor eficiencia en el sistema penal, a través del descongestionamiento de una justicia penal sobresaturada de casos para permitir el tratamiento de los más gra-

${ }^{30}$ Vitale, Gustavo, «Artículos 76 bis/quater» en Baigun, David; Zaffaroni, Eugenio Raúl (dirección); Terragni, Marco Antonio (coordinación) (2007), Código penal y normas complementarias. Análisis doctrinario y jurisprudencial», Tomo 2 b, artículo 56/78 bis. Parte General. Hammurabi, Buenos Aires, pág. 806.

${ }^{31}$ B.O. 19/5/1994 —adla, liv-b, 1400.

${ }^{32}$ Lanaro Ojeda, Gabriel Alberto y Sueiro, Carlos Christian, "La suspensión del juicio a prueba o "probation» y su incompatibilidad jurídico - normativa con los delitos de acción privada”, en La Ley 2008-b, 1136- Sup. Penal 2008 (marzo), 1. 
ves, resultando a la vez un medio idóneo de prevención especial y un ejemplo manifiesto de finalidad utilitaria. ${ }^{33}$

Respecto al concepto del instituto, el art. 76 bis del Código Penal, dice en su primera parte: "El imputado de un delito de acción pública reprimido con pena de reclusión o prisión cuyo máximo no exceda de tres años, podrá solicitar la suspensión del juicio a prueba”. Surge claro que este instituto solo puede ser instrumentado en los delitos de acción pública y no en los delitos de acción privada. En cuanto a los delitos dependientes de acción privada, una vez instada la acción no subsiste el inconveniente. Esto es pacíficamente receptado por la doctrina. ${ }^{34}$

Como se observa, este instituto implica una reducción del poder punitivo estatal. En este sentido, explica la jurisprudencia:

La suspensión del juicio a prueba importa una autolimitación del Estado en su pretensión punitiva y una excepción al principio de legalidad establecido a través de lo dispuesto en el artículo 71 del Código Penal, cuya infracción está conminada por el artículo 274 del mismo Código que no afecta la garantía de igualdad ante la ley prevista en el artículo 16 de la Constitución Nacional. ${ }^{35}$ (Conf. mi voto, CCyF, Sala III, in re causa 108-00/CC/2006 "Semprevivo, Sabrina s/ infr. art. 189 bis CP - apelación, considerando 4””)

De hecho, como anota Almeyra, constituye una importante limitación al principio de legalidad en la persecución penal, ${ }^{36}$ toda vez que, como se observa, el legislador, consciente de la realidad que hemos expuesto más arriba, optó por introducir criterios de oportunidad a través de la sanción de la Ley 24316.

Ahora bien, las polémicas en torno al instituto son varias, pero tocaremos solo las de mayor discusión en los últimos tiempos. En primer lugar, es indiscutible que la suspensión del juicio a prueba es un instituto eminentemente proce-

${ }^{33}$ D’Alessio, Andrés José y Divito, Mauro A. (2005), Código penal comentado y anotado, parte general (artículos $1^{\circ}$ a 78 bis) Tomo I, La Ley, 2005-743.

${ }^{34}$ Saenz, Ricardo O. «La suspensión del juicio a prueba (probation)», La Ley, 1994-c, 947.

${ }^{35}$ CCyF, Sala III, causa 108-00/cc/2006 “Semprevivo, sabrina s/ infr. art. 189 bis cp apelación”.

${ }^{36}$ Almeyra, Miguel Ángel, “Probation, ¿̇solo para los delitos de bagatela?”, La Ley 26/05/1995. 
sal, ya que no es sino un supuesto de disponibilidad de la acción ${ }^{37}$ y por ello, algo que afecta netamente al transcurso del proceso en sí, impidiendo la consecución normal del mismo a través de la celebración del juicio y su efecto inmediato, la sentencia. Aunque cierta parte de la doctrina sostenga que, al afectar a la acción, afecta al ordenamiento de fondo, toda vez que el régimen de la acción, como vimos, está receptado en el Código Penal, es un instituto de carácter procesal, pues para nosotros el ejercicio de la acción penal también es de naturaleza ritual o procesal.

Desde la naturaleza propia del instituto, la suspensión del juicio a prueba no puede ser otra cosa que un acuerdo de oportunidad entre quien detenta la acción penal pública, esto es, el fiscal -que estima que por razones de política criminal, de razonabilidad, de necesidad, eficacia y celeridad, procede otorgarlo-, y el imputado, que resultará beneficiado por la evitación del juicio (esto incluso es reconocido por la propia Cámara Nacional de Casación Penal, que ha dicho que

La suspensión del juicio a prueba en casos como el presente, consiste en evitar la efectiva aplicación de una norma de prisión en tanto no medien otros motivos valederos que justifiquen que la misma ha de ser de utilidad para los fines de prevención especial a que está dirigida. ${ }^{38}$

Dicho acuerdo, contiene ciertas pautas de conducta a cumplir y está sujeto a determinados requisitos previos y luego de una audiencia de control o "de visu”, ante el Juez o Tribunal, este debe homologarlo o no, pero no trastocar sus términos, pues de hacerlo estaría abandonando su función de garante, poniéndose en la piel del acusador, algo que no le está permitido en el modelo acusatorio que se propugna. Lo que sugerimos, surge de la propia letra de lo que el legislador nos dejó. Analicemos los distintos ordenamientos.

El legislador nacional previó que la suspensión del juicio a prueba se otorgue bajo los siguientes requisitos:

a) Se debe tratar de un delito de acción pública, reprimido con pena de prisión, que no exceda en abstracto la pena de tres años. Esto excluye

${ }^{37}$ Freeland Lopez Lecube, Alejandro y Tamini, Adolfo Luis, “La 'probation’ y la suspensión del juicio penal a prueba (comentarios a la ley 24.316.)”, La Ley, 1994-d, 854.

${ }^{38}$ Cámara Nacional de Casación Penal, Sala III, 20/05/2005, “Layun, Martín A. s/rec. de casación”, en La Ley online. 
delitos de instancia privada (mientras no se transformen en acciones públicas) y de acción privada, delitos con penas superiores a los tres años en abstracto y delitos con penas de inhabilitación o multa.

b) El imputado -que es quien lo solicita- debe ofrecerse reparar el daño causado y abandonar los bienes decomisados en el delito a favor del estado. Esta reparación del daño, debe guardar cierta relación con el daño causado y no puede ser meramente nominal o exigua. Al respecto, se ha dicho que

Si la reparación del daño ofrecida por el imputado al momento de solicitar la suspensión del juicio a prueba, no cubre siquiera mínimamente el daño material y moral causado por el delito y resulta exigua en comparación con sus posibilidades económicas, resulta improcedente conceder el beneficio porque, aunque es cierto que la reparación exigible no debe ser necesariamente equiparable al daño causado, al menos ha de lograrse el máximo esmero en lograr la satisfacción total del damnificado. ${ }^{39}$

c) Durante su vigencia (entre uno y tres años) el imputado no puede cometer delito, pues ello hace caer al instituto y reanuda el juicio.

d) Se puede conceder una nueva suspensión del juicio a prueba a la misma persona, si entre el primer delito y el segundo, transcurrieron más de ocho años desde el plazo de expiración supuesta de la primera suspensión del juicio a prueba. Si las pautas de conducta se incumplieron, no puede volver a solicitarse una suspensión del juicio a prueba.

La mayoría de los requisitos que aquí hemos anotado han sido receptados en el Plenario “Kosuta”, de la Cámara Nacional de Casación Penal, ${ }^{40}$ los que a su vez han sido aceptados por la Corte Suprema de Justicia de la Nación, en el precedente «Gregorchuk», ${ }^{41}$ donde específicamente se dice que

Esta Corte comparte y hace suyos los argumentos expuestos por la Cámara Nacional de Casación Penal en el fallo plenario «Kosuta,

${ }^{39}$ Cámara de Apelaciones y Garantías en Lo Penal de San Martín, Sala III, 08/02/2006. Urbieta, Carolina. LLBA 2006, 967. ar/jur/890/2006.

${ }^{40}$ Plenario No 5, del 17/08/1999, publicado en La Ley, 1999-e, 165, 828; dj, 1999-3-309.

${ }^{41}$ G. 663.XXXVI Rta. el 3/12/02. 
Teresa Ramona s/recurso de casación» de fecha 17 de agosto de 1999, en lo que atañe a cuál es el criterio interpretativo para establecer el límite de la escala penal que habilitaría la viabilidad del instituto, así como también en lo que respecta a su improcedencia en aquellos supuestos en que respecto del delito imputado esté prevista pena de inhabilitación como principal, conjunta o alternativa.

Y las pautas las fija el tribunal. En este aspecto, el instituto tiene otra dimensión en varios de los ordenamientos procesales provinciales que lo han regulado, en sintonía con lo que hemos dicho párrafos arriba, esto es, que se trata de un instituto de naturaleza procesal y por ende, no delegado en su legislación por las provincias a la Nación.

Por ejemplo, el Código Procesal Penal de la Ciudad de Buenos Aires, que regula el instituto en su art. 205, dice:

En cualquier momento de la investigación preparatoria y hasta inmediatamente antes del debate o durante éste cuando se produzca una modificación en la calificación legal que lo admita, el/la imputado/a podrá proponer la suspensión del proceso a prueba. El tribunal convocará a una audiencia oral con citación al peticionario, al Ministerio Público Fiscal y a la querellante, si lo hubiere, o a la víctima. Luego de escuchar a las partes resolverá si concede la suspensión de la persecución penal, con las condiciones de cumplimiento que estime pertinentes, o la deniega. La oposición del Ministerio Público Fiscal, fundamentada en razones de política criminal o en la necesidad de que el caso se resuelva en juicio, será vinculante para el tribunal. Contra la decisión no habrá recurso alguno. Cumplidas las condiciones impuestas, el/la juez/a, previa vista al Ministerio Público Fiscal, dictará sobreseimiento. En caso de incumplimiento dispondrá la continuación del proceso o la prórroga de la suspensión, según corresponda.

Aquí, como vemos, se habla de “partes” y la suspensión del juicio a prueba sí surge como un acuerdo entre partes, que es sometido a consideración del Tribunal, que resuelve concederlo o denegarlo, previa audiencia. Aquí, el fiscal puede oponerse, basándose en criterios de política criminal, lo cual será vinculante para el tribunal (lo contrario, transformaría al tribunal en detentador de la ac- 
ción pública. Y de hecho, en la Ciudad de Buenos Aires, es el fiscal quien acuerda con el imputado la suspensión del juicio, como forma alternativa de solución. Ello surge del art. 206, que comienza diciendo: "Cuando el/la Fiscal considere que se encuentra agotada la investigación preparatoria y que no va a proponer otra forma de resolución del conflicto o ésta hubiera fracasado, formulará el requerimiento de juicio", o sea que si el fiscal no acuerda con el imputado, formulará el requerimiento pertinente.

Algo similar, pero más perfeccionado, es lo que ocurre en ordenamientos procesales aún más novedosos que el porteño, como el Código Procesal Penal de Chubut, que en su art. 49, dice:

Cuando la ley penal permita la suspensión de la persecución penal, el imputado o su defensor podrán requerirla durante la audiencia preliminar. La petición será tratada en la misma audiencia con intervención de las partes; si el ofendido no participare o no estuviere representado en el procedimiento, la audiencia se suspenderá para permitir su citación. Concluido el tratamiento de la cuestión, el juez dictará la decisión interlocutoria sobre la suspensión del juicio. En caso de conceder la suspensión, la parte resolutiva de la decisión fijará el plazo de prueba y establecerá las reglas de conducta que deberá cumplir el imputado; en el caso contrario, rechazará explícitamente la suspensión y ordenará continuar la audiencia. Ante la oposición de la víctima, si el juez concede la suspensión del juicio a prueba, en la resolución y en forma fundada deberá expresar los motivos que tuvo en cuenta para desestimar dicha oposición. La suspensión del juicio podrá ser solicitada hasta la culminación de la etapa preparatoria.

Asimismo, el Art. 50 dice:

Al resolver la suspensión del procedimiento, el juez fijará un plazo de prueba de acuerdo a lo establecido en el Código Penal, determinando fundadamente las condiciones y reglas que deberá cumplir el imputado en ese período. El juez comunicará personalmente al imputado la suspensión condicional del procedimiento, con expresa advertencia sobre las reglas de conducta y sobre las consecuencias de su inobservancia. Si en este plazo el imputado no comete nuevo delito, y cumple las reglas impuestas, deberá declararse extinguida la acción. 
Aquí, como se ve, también se habla de "partes", también se habla de la víctima u ofendido, y también es un acuerdo entre ellos, sometido al control jurisdiccional.

Es que la verdadera razón de ser del instituto, como ya lo dijéramos, es establecer, a través de un criterio de oportunidad, una solución alternativa al conflicto, en la medida de lo razonable, teniendo en cuenta las características del hecho, el perjuicio causado tanto al bien jurídico protegido por la norma infringida como al afectado y las circunstancias personales del autor. Así, la suspensión del juicio a prueba no puede ser otra cosa que un acuerdo entre partes, sometido a control jurisdiccional, sujeto a requisitos y con el cumplimiento obligatorio de determinadas pautas de conducta.

Una última polémica radica en si ese acuerdo es factible de ser rechazado por el afectado, quien -constituido como querellante-puede rechazar el acuerdo hecho entre fiscal e imputado y solicitar al tribunal que, mediante un ejercicio de su derecho a la jurisdicción, lleve el caso a juicio oral. Al respecto, y siguiendo la letra del Código Penal, la postura mayoritaria sostiene que la opinión del afectado o víctima o querellante no es vinculante y que llegado el caso podrá optar por continuar con la acción como si se tratare de un delito de acción privada, o que incluso podría recurrirlo. En este sentido, la Sala IV de la Cámara Nacional de Casación Penal dijo que

La reparación de daño causado ofrecida por el imputado, no representa un requisito sine qua non para la procedencia de la suspensión del juicio a prueba por cuanto, la ley dispone que la aceptación de la víctima no es vinculante. ${ }^{42}$

Una postura que reivindica la autonomía del querellante y la nueva reafirmación de la víctima como sujeto activo del proceso, sostiene la posibilidad de que estos ofrezcan reparos al otorgamiento de una alternativa al conflicto penal al imputado, sin que su voz tenga carácter vinculante. ${ }^{43}$

${ }^{42}$ Cámara Nacional de Casación Penal, Sala IV. 12/02/2009. Costa Mendoza, Mercedes, dj 19/08/2009, 2345.

${ }^{43}$ Por ejemplo, ver Castex, Francisco (2010), “La autonomía del querellante”, en La Ley, sup. penal (septiembre), 168. 


\section{La mediación penal}

Hoy en día, como bien dice Maihofer -citado por Roxin-, la intervención de la víctima en la resolución del conflicto del cual fue co-protagonista, no pretende volver a la venganza ni es una privatización del sistema, sino que abre una tercera vía, la de la reparación, que contribuye en gran medida a una mejora del clima social. ${ }^{44}$ Dentro de este concepto, ante la falta de respuesta del modelo tradicional legalista, ha surgido un interés respecto de la corriente que pregona el desarrollo de métodos alternos de resolución de conflictos.

Entre esos institutos, el segundo que anotaremos es la mediación penal. Este instituto comenzó a aplicarse a mediados de los años 70 en procesos penales estatales, en California, EE.UU. En nuestro país el modelo conciliatorio se utiliza para los delitos de acción privada y solo se lleva a cabo si la víctima y victimario están de acuerdo en hacerla.

Al respecto, la mediación en sí no es sino un método horizontal de relación entre partes de un conflicto derivado de la infracción de una norma penal, generalmente de baja intensidad, donde el Estado, representado en la figura de un "mediador", intenta coadyuvar a que las partes identifiquen el conflicto y en una o varias audiencias intenten acercar posiciones y llegar a una solución o acuerdo, el que queda por escrito, tiene carácter de instrumento público y, luego de ser homologado por el Tribunal competente, pone fin al caso iniciado.

Este novedoso instituto ya ha sido puesto en marcha en varios ordenamientos procesales penales provinciales con excelentes resultados, restándole el avance al proceso nacional. Así, la Provincia de Buenos Aires lo ha puesto en marcha con la sanción de la Ley $12061^{45}$-la Ley Orgánica del Ministerio Público bonaerense-, que en su Art.38 dice: "Formas de conciliación. El Ministerio Público propiciará y promoverá la utilización de todos los mecanismos de mediación y conciliación que permitan la solución pacífica de los conflictos”. Posteriormente, en el año 2006, se sancionó la Ley 13.433 de Mediación

${ }^{44}$ Roxin, Claus (1992), La reparación en el sistema de los fines de la pena, en de los delitos $y$ de las víctimas, Ad Hoc, Buenos Aires. Al respecto dice: "en un derecho penal entre libres e iguales, la reparación debe ser la sanción primera, la terminación del conflicto por composición y por compensación del daño, el procedimiento preferido”. Maihofer, citado por Roxin, Claus, ob. cit., pág. 141.

${ }^{45}$ Sancionada el 11/12/1997. 
Penal, donde queda establecido que "El procedimiento de los mecanismos de resolución alternativa de conflictos penales se regirá por los principios de voluntariedad, confidencialidad, celeridad, informalidad, gratuidad, y neutralidad o imparcialidad de los mediadores. Siempre será necesario el expreso consentimiento de la víctima". ${ }^{46}$

La Ciudad de Buenos Aires también ha puesto en marcha, con su nuevo y ya citado Código Procesal Penal, al instituto de la mediación penal como método alternativo de solución de conflictos al que puede apelar el fiscal si tanto él como la víctima como el imputado acuerdan hacerlo. Así, el Art. 204 inc. $2^{\circ}$, dice:

Art. 204. Vías alternativas. En cualquier momento de la investigación preparatoria el/la Fiscal podrá: (...) 2) proponer al/la imputado/a y/o al/la ofendido/a otras alternativas para la solución de conflictos en las acciones dependientes de instancia privada o en los casos de acción pública en que pueda arribarse a una mejor solución para las partes, invitándolos a recurrir a una instancia oficial de mediación o composición. En caso de acuerdo el/la Fiscal dispondrá el archivo de las actuaciones sin más trámite.

No obstante, y pese a lo que esta norma prescribe, la Cámara de Apelaciones en lo Penal y Contravencional de la Ciudad (que es la segunda instancia del Fuero que aplica el CPPCABA), se ha opuesto a esta norma, aduciendo que:

Las normas que regulan este instituto adolecen de suma vaguedad y ambigüedad, hallándose carentes de solución infinidad de situaciones, como la del imputado que se encuentra detenido, o que posee condenas anteriores, o a quien se le atribuye un delito de cierta gravedad a la luz de su escala punitiva, hipótesis que podrían interpretarse -así lo hace la defensa-como abarcadas por la posibilidad de mediación -con excepción de aquellos delitos que se encuentran específicamente excluidos-. Es decir que la regulación de esta vía posee contornos muy difusos, a lo que se suma la ausencia de todo mecanismo de control. Empero, a la luz de la normativa de

${ }^{46}$ Art. 3 de la Ley 13433, sancionada el 9/01/2006.

${ }^{47}$ CAPCFCABA - Sala I - 29/05/2009, causa nº 45966-02-cc/09 - «Incidente de nulidad en autos `González, Pedro s/infr. art. 183 -daños -cp». 
fondo, el principio general que rige en nuestro derecho es el de legalidad, que impone que la persecución penal se realice ex officio. Ello implica que el Estado tiene el derecho y la obligación de perseguir penalmente en todos los casos previstos por la ley como delito, realizando su pretensión por sí mismo, sin consideración a la voluntad del ofendido. ${ }^{47}$

Por si quedan dudas respecto de si se trata de un pensamiento aislado o corporativo, en un precedente similar, otra Sala del mismo Tribunal sostuvo que

En este punto es dable destacar que esta Sala comparte en su totalidad las consideraciones vertidas por nuestros colegas de Tribunal (ver al respecto, Sala I, c. 45966-02-CC/09, Incidente de nulidad en autos “González, Pedro s/ infr. art. 183 CP”, rta.: 29/05/2009; y Sala III, c. 45966-02-CC/09, Incidente de nulidad en autos "Batista, Ramón Andrés Pedro s/ infr. art. 149 bis CP”, rta.: 10/06/2009), a las que nos remitimos a fin de evitar reiteraciones innecesarias. En tal sentido, en dichos precedentes se ha señalado suficientemente que el diseño del instituto en el ámbito local carece de un marco regulatorio adecuado, no solo por la vaguedad de los términos utilizados y las escasas referencias normativas existentes -lo cual ha permitido diversas y disímiles interpretaciones que terminan por desnaturalizar la aplicación de la mediación- sino también por su contraposición con principios generales emanados de la legislación nacional que no pueden ser desoídos en razón de su jerarquía normativa superior. Sobre este aspecto, también se ha destacado en los precedentes de este Tribunal ya citados, la incompatibilidad de lo legislado en el ámbito local con la norma prevista en el art. 71 del Código Penal que consagra el principio de legalidad de la acción penal. ${ }^{48}$

Luego, la solución a la que apelaron las tres salas de la Cámara fue la de declarar la inconstitucionalidad de oficio (pues era una cuestión que ni siquiera se había planteado) de la mediación penal.

Por suerte para nuestra posición, el Tribunal Superior de Justicia de la Ciudad de Buenos Aires, en el precedente "Del Tronco”, echó un poco de luz, ya que de ser por los Magistrados de la Cámara porteña, la mediación y el principio de oportunidad habían quedado desterrados del catálogo práctico y con ello se hubiera llegado a la parálisis del Fuero, tal como ocurre hoy en la 
Justicia Nacional. Al respecto, el más Alto Tribunal de los porteños dijo, en la voz del dr. Lozano:

En realidad, el a quo declaró inconstitucional el art. 204 inc. 2 del CPPCABA en cuanto allí se regula un mecanismo de acercamiento entre partes, en un conflicto, cuyo propósito es buscar una composición concertada de los intereses (susceptibles de juzgamiento o no, y sean estos o no los que están en colisión) de esas partes y que se traduce en productos diversos, consistentes en compromisos con diversa solemnidad, pero, sin descartar opciones unilaterales que tienen en mira las respuestas de la otra parte que se hacen previsibles a partir de lo actuado en el marco del desarrollo de la mediación, relacionados siempre con aquello de que las partes pueden disponer. ${ }^{49}$

Y luego de ello, se deja sin efecto la declaración de inconstitucionalidad mentada.

Queremos destacar un párrafo del voto de la dra. Conde en el precedente citado: "En efecto, mientras de manera dogmática se sostiene el postulado de la "legalidad" el sistema penal evidencia una realidad esencialmente distinta: la persecución penal oficiosa, incondicionada y fatal de todos los delitos que son denunciados es impracticable".

Como corolario, diremos que la mediación penal es una alternativa diseñada para procesos de baja intensidad, donde, merced al acuerdo de Estado, víctima e imputado debidamente asistido, se le da al conflicto presentado una solución más acorde con su naturaleza real y dinámica, algo en lo que creemos profundamente.

${ }^{48}$ CAPCFCABA - Sala II - 26/06/2009, causa n 11917-00-cc/09- “Domínguez, Luis Emilio infr. art. 184, inc. 5, cp - apelación”.

${ }^{49}$ TSJBA, 27/09/2010, expte. n 6784/09 ministerio público — defensoría general de la ciudad de buenos aires - s/ queja por recurso de inconstitucionalidad denegado en: 'del tronco, nicolás s/ infr. art. 184 inc. 5 — cp—”” y expte. nº 6785/09 “Ministerio Público —fiscalía ante la cámara de apelaciones con competencia en lo penal, contravencional y de faltas $n^{\circ} 1-s$ / queja por recurso de inconstitucionalidad denegado en: ‘del tronco, nicolás s/ infr. art. 184 inc. 5 —cp”. 


\section{Juicio o procedimiento abreviado}

El tercer instituto a comentar es el denominado "Procedimiento o Juicio abreviado", que no es otra cosa que un acuerdo entre fiscal e imputado sobre las condiciones de culpabilidad y consiguiente pena a cumplir por el hecho cometido, tendiente a la evitación del juicio oral y público cuando este no sea imprescindible para arribar a una sentencia que resuelva el caso. ${ }^{50}$

Aquí, técnicamente, no se afecta el principio de legalidad, puesto que en realidad no se implanta principio de oportunidad alguno, ya que se respetan las penas establecidas en el Código Penal, no se acepta una calificación legal diferente a la prescripta ni se admite probado un hecho distinto al ocurrido y, fundamentalmente, la conclusión del proceso se da con la sentencia, que es como el principio de legalidad prescribe que debe finalizar.

En cuanto a sus antecedentes, el más conocido es el instituto llamado "plea bargaining”, o negociación de culpabilidad, que es un mecanismo de solución negociada del caso penal, básicamente entre el fiscal y el abogado defensor; un trato mediante el cual la acusación se aviene a pedir una sentencia más benigna o a abandonar alguno de los cargos o dar alguna otra ventaja al acusado a cambio de que este se declare culpable, lo que evita tener que ir al juicio oral por jurado. ${ }^{51}$ También en Italia, con el nuevo Código de Procedimiento Penal de 1989, en el Libro VI, se contienen varias especies del genérico «proceso penal abreviado», los cuales, son: el «juicio abreviado» propiamente dicho, cuya causa en juzgamiento se define en la «audiencia preliminar» buscándose una solución anticipada del caso y posibilitando una disminución de pena; la «aplicación de la pena a solicitud de parte», que tiene el acuerdo sobre la sanción penal como médula; «el juicio directísimo», que contempla supuestos de flagrancia y confesión; el «juicio inmediato», que procede cuando la prueba es evidente y el «procedimiento por decreto», un procedimiento monitorio, condena sin debate con impugnación tardía. Por último, la Ordenanza Penal Alemana prevé dos especies de procedimientos abreviados; el primero de ellos, conocido como «procedimiento por mandato», puramente escrito, tiene su génesis en la petición fiscal formulada a manera de acusación respecto a delitos cuya pena máxima no supere los dos años. Dicha petición

${ }^{50}$ Cafferata Nores, José I. (1997), Cuestiones actuales sobre el proceso penal. Juicio penal abreviado, Del Puerto, Buenos Aires, págs. 77-87.

${ }^{51}$ Ver más detalladamente en Hendler, Edmundo S. (2004), Derecho penal y derecho procesal penal en los estados unidos”, Ad-Hoc, Buenos Aires. 
fiscal se circunscribe a limitar la materialidad del hecho, la responsabilidad jurídico penal y la autoría del imputado, juntamente con el pedido concreto de pena. El juez competente para librar el mandato judicial es el de primera instancia. El restante procedimiento especial denominado «procedimiento acelerado», fue incorporado en la reforma del año 1994. Las diferencias sustantivas con el «procedimiento por mandato» radican en el mayor poder decisorio que poseen los jueces de primera instancia, la exclusión de los menores a la aplicación del, y el sistema oral. Frente a la acusación fiscal (escrita u oral), se celebra una vista de causa, cuyo plazo es leve, destinada casi exclusivamente a la producción de prueba de las partes integran intervinientes. Hecho esto, el tribunal no puede imponer una condena privativa de libertad superior a un año ni medidas de seguridad o de corrección. Generalmente su aplicación está reducida a hechos de violencia llevados a cabo durante espectáculos públicos o de gran aglomeración de persona, $\mathrm{y}$ en los supuestos de flagrancia.

A nivel local, existen varios antecedentes. El Código Procesal de la Provincia de Córdoba regula el juicio abreviado en el art. 415, el que prevé que "si el imputado reconoce el hecho por el que se le sigue la causa, podrá omitirse la recepción de la prueba tendiente a acreditarla, siempre que estuvieran de acuerdo el tribunal, el fiscal y los defensores”. En tal caso, la sentencia se fundará en las pruebas recogidas en la investigación penal preparatoria y no se podrá imponer al imputado una sanción más grave que la pedida por el fiscal. En la provincia de Buenos Aires, el juicio abreviado se regula en el art. 395 y siguientes, de su Código Procesal Penal, donde se establece que el acuerdo será entre el fiscal, el imputado y su defensor, y solo se podrá solicitar en caso de estimarse que la pena a imponer, será privativa de la libertad no mayor de seis años, o una no privativa, procedente aún en forma conjunta. Formosa y Santa Cruz también lo han regulado en forma previa a la Nación, al igual que Tierra del Fuego, que en su Art. 324 suprime la "audiencia de discusión”, dictándose sentencia sin que dicha audiencia se realice, en forma cuasi idéntica a lo que ocurre en los demás órdenes mencionados.

En el orden legislativo nacional, fue incorporado con la Ley $24825^{52}$ y agregada al Código Procesal Penal de la Nación, en el Libro III, Título II, en el capítulo IV. Al respecto, dice el Art. 431 bis:

${ }^{52}$ Promulgada el 11 de junio de 1997. 
1. Si el ministerio fiscal, en la oportunidad prevista en el art. 346, estimare suficiente la imposición de una pena privativa de libertad inferior a seis (6) años, o de una no privativa de libertad aun procede en forma conjunta con aquélla, podrá solicitar, al formular el requerimiento de elevación a juicio, que se proceda según a este capítulo. En tal caso, deberá concretar expreso pedido de pena. En las causas de competencia criminal (art. 32), el acuerdo a que se refieren los incisos $1^{\circ}$ y $2^{\circ}$ del artículo 431 bis, podrá también celebrarse durante los actos preliminares del juicio, hasta el dictado del decreto de designación de audiencia para el debate (art. 359). 2. Para que la solicitud sea admisible deberá estar acompañada de la conformidad del imputado, asistido por su defensor, sobre la existencia del hecho y la participación de aquél, descriptas en el requerimiento de elevación a juicio, y la calificación legal recaída. A los fines de este artículo y en cualquier etapa del proceso, pero desde la aceptación del cargo del defensor designado, el fiscal podrá recibir en audiencia al imputado y a su defensor, de lo que se dejará simple constancia. 3. El juez elevará la solicitud y conformidad prestada, sin otra diligencia, al tribunal de juicio al que, tomará conocimiento de visu del imputado y lo escuchará si éste quiere hacer alguna manifestación. Si el tribunal no rechaza la solicitud argumentando la necesidad de un mejor conocimiento de los hechos o su discrepancia fundada con la calificación legal admitida, llamará a autos para sentencia, que deberá dictarse en un plazo máximo de diez (10) días. Si hubiera querellante, previo a la adopción de cualquiera de estas decisiones, le recabará su opinión, la que no será vinculante. 4. Si el tribunal del juicio rechaza el acuerdo de juicio abreviado, se procederá según las reglas del procedimiento común con arreglo a los arts. 354 o 405, según corresponda, remitiéndose la causa al que le siga en turno. En tal caso, la conformidad prestada por el imputado y su defensor no será tomada como un indicio en su contra, ni el pedido de pena formulado vincula al fiscal que actúe en el debate. 5. La sentencia deberá fundarse en las pruebas recibidas durante la instrucción, y en su caso en la admisión a que se refiere el punto 2, y no podrá imponer una pena superior o más grave que la pedida por el ministerio fiscal. Regirá el art. 399. 6. Contra la sentencia será admisible el recurso de ca- 
sación según las disposiciones comunes. 7. La acción civil no será resuelta en este procedimiento por juicio abreviado, salvo que exista un acuerdo entre las partes en tal sentido, aunque se podrá deducir en sede civil. Sin embargo, quienes fueron admitidos como partes civiles podrán interponer el recurso de casación en la medida que la sentencia pueda influir sobre el resultado de una reclamación civil posterior. 8. No regirá lo dispuesto en este artículo en los supuestos de conexión de causas, si el imputado no admitiere el requerimiento fiscal respecto de todos los delitos allí atribuidos, salvo que se haya dispuesto la separación de oficio (art. 43). Cuando hubiera varios imputados en la causa, el juicio abreviado solo podrá aplicarse si todos ellos prestan su conformidad.

De todo lo transcripto, surge que el juicio abreviado aparece como un acuerdo entre fiscal e imputado sobre la pena a imponer - que debe estar dentro de la escala aplicable a la figura calificada en razón del hecho cometido y probado -, la que luego debe ser tomada por el Tribunal y dictada la correspondiente sentencia. Para ello, deben cumplirse una serie de requisitos:

a) $\mathrm{Al}$ momento del requerimiento de juicio, el Fiscal debe haber estimado como suficiente una pena inferior a los seis años de pena privativa de libertad. En tal caso, ya puede hacer la petición de juicio abreviado, solicitando la pena a imponer.

b) La solicitud debe estar firmada por Fiscal, imputado y defensor, debe contener la descripción del hecho y su calificación legal que debe ser el mismo por el cual fue requerido a juicio.

c) El juez toma vista y eleva al tribunal de juicio que, previa audiencia personal con el imputado, luego de diez días, dicta sentencia.

d) La opinión del querellante será tenida en cuenta pero no será vinculante.

e) No se resuelve la acción civil y solo se admite el recurso de casación.

Mucho se ha escrito, a favor y en contra de este verdadero engendro jurídico. Se ha expresado que los procedimientos abreviados representan los instrumentos indispensables para el concreto funcionamiento el sistema, en cuanto permiten adecuar con flexibilidad la elección del rito al caso concreto. Ferrajoli critica este instituto, distinguiendo el «pacto sobre la pena» del «pacto sobre el procedimiento», además de decir que en los casos de abreviación se llegaría 
hasta derogar el principio nulla poena sine judicio, y expresar que alegar que las formas del acuerdo son un resultado lógico del sistema acusatorio y de un proceso de partes, resulta ser ideológico y mistificador. Para el maestro italiano, el juicio abreviado no es sino la perversión del sistema de garantías en pos de la eficacia del sistema procesal que el Estado ha decidido implantar. ${ }^{53}$

También la jurisprudencia, tanto provincial como nacional, se ha propiciado a favor del juicio abreviado, argumentando que, de no observarse vicios en él o mientras el imputado haya contado con el debido asesoramiento letrado, es un acuerdo perfectamente válido. Así, se ha dicho que

Resulta improcedente el planteo de inconstitucionalidad del procedimiento de juicio abreviado efectuado por la defensa -en el caso, se había dictado sentencia condenatoria-, pues más allá de que las partes acuerden una calificación legal y una pena, dichos extremos representan para los magistrados un «techo» que no pueden rebasar al dictar sentencia, pero conservan la posibilidad de imponer una calificación menos gravosa, una pena inferior, o incluso absolver con lo que, más allá de las particularidades propias de este tipo de proceso, no puede predicarse que no abastezca el requisito de «juicio previo» constitucionalmente reconocido. No existe afectación al derecho de defensa del imputado que conlleve a la declaración de inconstitucionalidad del procedimiento de juicio abreviado -en el caso, se dictó sentencia condenatoria-, porque el derecho de defensa de los acusados se vio garantizado con la asistencia técnica del letrado defensor previo a la formalización del acuerdo y no existieron vicios en las voluntades al momento de suscribirlo. ${ }^{54}$

La propia Corte nacional, en el precedente "Arduino”, ha dicho que Es improcedente el cuestionamiento de la validez del acuerdo de juicio abreviado celebrado con el representante del Ministerio Público Fiscal,

${ }^{53}$ Ferrajoli, Luigi (1998), Derecho y razón, Trotta, Madrid, pág. 748. En concreto, dijo: “¿qué puede dar el sospechoso, en su confrontación desigual con la acusación, a cambio de la reducción de la condena, sino la propia declaración de culpabilidad o la admisión, incluso infundada, de haber codelinquido con los demás acusados?”.

${ }^{54}$ Tribunal de Casación Penal de Buenos Aires, 22/07/2008. C., J. M. y otro, La Ley online; ar/jur/7953/2008 
toda vez que del legajo no surgen elementos que permitan dar sustento a la supuesta coerción psicológica o al insuficiente asesoramiento que adujo el justiciable. Así como la voluntad del encausado es la que debe prevalecer para que una sentencia condenatoria no quede firme por la sola conformidad del defensor, también es jurídicamente relevante para decidir su acogimiento al régimen de juicio abreviado -que requiere «la conformidad del imputado»- cuando, como en el caso, ella se ha prestado en forma reiterada, según los recaudos que establece el art. 431 bis del Cód. Procesal Penal, y no se acreditó ni invocó la existencia de elementos que permitan suponer que medió algún vicio de la voluntad..$^{55}$

La aceptación del instituto, a nivel jurisprudencial, es pacífica.

Las propias legislaciones procesales penales provinciales lo han receptado luego que la Nación lo hiciera, continuando con la tradición bonaerense o cordobesa. Así, la Ciudad de Buenos Aires -que lo denomina más correctamente y con mayor apego a la realidad "avenimiento"- lo legisla en su art. 266:

En el momento de la intimación al imputado por el hecho o a partir de ese momento en cualquier etapa del proceso hasta los cinco días posteriores a la notificación de la audiencia de debate, el/la Fiscal podrá formalizar con el/la imputado/a y su defensor/a, un acuerdo sobre la pena y las costas. El acuerdo debe contener los requisitos del requerimiento de juicio, o remitirse a ese acto si ya se hubiera formulado y la conformidad del/la imputado/a, con asistencia de su defensor/a, la que importará la aceptación sobre la existencia del hecho o de los hechos reprochados y su participación, con la calificación legal adoptada y con la pena solicitada. El/la Juez/a citará al/la imputado/a a una audiencia de conocimiento personal, lo interrogará sobre sus circunstancias personales y sobre si comprende los alcances del acuerdo. Luego deberá homologar el acuerdo o rechazarlo y disponer que continúe el proceso, por auto, si considerase que la conformidad del/la imputado/a no fue voluntaria. La homologación podrá adoptar una calificación legal o una pena más favorable al/la imputado/a y tendrá todos los efectos de la sentencia definitiva. Contra el rechazo habrá recurso de apelación.

${ }^{55}$ CSJN, 22/03/2005. Arduino, Diego J. y otro; dj 2005-2, 1079; ar/jur/1234/2005. 
En contra del instituto también se ha escrito mucho. Ya hemos citado al ilustre Ferrajoli. También se ha dicho que

el juicio abreviado, así regulado, encierra mucho más que la idea de suprimir la audiencia de debate, y el ideal de la verdad real, que se habría intentado mantener como meta del proceso penal, se degrada mucho más allá de lo que debiera implicarlo, ya de por sí, la omisión de la recepción de la prueba en forma oral y pública y en un marco contradictorio y continuo.

Y que "el juicio abreviado exige al imputado que aporte un elemento de prueba más en su contra: su propia admisión sobre los distintos extremos de la imputación, que, eventualmente, servirá para fundar una sentencia de condena". En esta posición, se cree, con acierto, que la admisión del imputado no puede ser utilizada como medio de prueba en un procedimiento que tiene por finalidad la búsqueda de la verdad real y se cuestiona por qué le es exigida al imputado como contraprestación para que se apliquen al proceso las reglas del juicio abreviado.

Salazar Rodríguez y varios otros doctrinarios consideran que si el abreviado se propone ser un mecanismo de negociación entre partes, debe partir de la base de una igualdad de posiciones para acordar, y su correlato: la equivalencia de las prestaciones y que nada de ello se da en un acuerdo en que el imputado no solo relega su posibilidad de ir a debate, sino que también extiende su conformidad con los términos de la acusación, a cambio de que el fiscal únicamente ofrezca una presunta reducción de su pretensión punitiva, quizás a un mínimo legal, pero prácticamente asegurándose la condena que pretende, ya que, gracias a ese acuerdo, no solo cuenta con la prueba reunida en la investigación, que no será cuestionada en un debate, sino también con la conformidad del imputado, que puede ser tomada como un elemento de prueba en su contra, o algo mucho peor: dejar la falsa sensación en el juzgador de que, gracias a ella, si la prueba de cargo no es contundente, pareciera más acertada una condena que una absolución, invirtiéndose el principio in dubio pro reo. ${ }^{56}$

Nosotros creemos que el abreviado surge como un engendro donde el Estado reconoce su incapacidad de poder llevar a debate todos los casos que se

${ }^{56}$ Entre otros, merecen destacarse las críticas vertidas en Salazar Rodriguez, Luis Alonso (1998), «Suspensión del procedimiento a prueba y proceso abreviado. Un problema de 
le plantean, como ocurre con el establecimiento de los criterios de oportunidad, y en virtud de ello sacrifica algunas aristas de un proceso normal, las que generalmente perjudican a la víctima o al imputado. Presentar el juicio abreviado como un acuerdo es una verdad a medias, pues un acuerdo supone igualdad de condiciones entre las partes y claramente en el abreviado, el imputado está en desigualdad. Por ello, se acerca más a un contrato de adhesión, a un avenimiento como correctamente lo denominan los porteños, donde la desigualdad se intenta achicar con la presencia del letrado defensor, con la legalidad de las pruebas aportadas, con la calificación legal y la escala penal inamovibles en relación al hecho cometido y a las condiciones personales del autor al momento del mismo, pero que se agranda con la presencia de un elemento probatorio muy poderoso, que es la aceptación de culpabilidad del imputado. Esto claramente puede ser tamizado por el órgano jurisdiccional, que se encargará de velar por el adecuado cumplimiento de las garantías del imputado, por los derechos de la víctima y por el respeto del proceso, y así verificará que, más allá de la asunción de culpabilidad, exista relación entre hecho y pena y en todo caso podrá anular el avenimiento y enviar todo al debate.

Toda institución procesal tiene pros y contras. Creemos que el juicio abreviado necesita alguna vuelta de tuerca más, pero su aporte es innegable.

\section{Bases ideológicas de las últimas reformas procesales en la Argentina}

A lo largo de las últimas décadas, en prácticamente todos los países de América Latina, y muy especialmente en Argentina, se ha venido desarrollando un movimiento de reforma cuya impronta ha sido transformar el modo de administración de la justicia penal en la Argentina, en la creencia que, como venía evidenciándolo la estadística y la realidad judicial, el viejo modelo había fracasado.

constitucionalidad», en Cuadernos..., T. 8 a., pág. 564, Ad-Hoc, Buenos Aires; Diaz Canton, Fernando, «Juicio abreviado vs. Estado de derecho», en El procedimiento abreviado, ob. cit., págs. 251 y ss., en particular, pág. 269, quien sostiene que algunos se animan a asociar la certeza pactada con un nuevo concepto de verdad procesal, de tipo consensual, cuando en verdad debieran decir «verdad impuesta»; Bovino, Alberto, «Procedimiento abreviado y juicio por jurados», en: El procedimiento abreviado, ob. cit., pág. 87; Anitua, Gabriel Ignacio, «En defensa del juicio», en Cuadernos..., t. 8-a, pág. 549; Pereyra, Pablo E, "Los alcances de la conformidad del imputado en el juicio abreviado: el reflejo de una confrontación desigual», La Ley 2001-e, 790-sup. penal 2001 (octubre), 15. 
Según el viejo modelo autoritario, el Estado se caracteriza por tener un sistema de persecución penal teñido por fuertes rasgos inquisitivos, en el que no existe respeto por los derechos individuales y el objetivo fundamental es conseguir la verdad, sin darle importancia al modo en que esta consecución se realice. Por el contrario, en los Estados democráticos, donde existe un equilibrio entre el poder estatal y las garantías de los individuos, se caracterizan por tener un sistema acusatorio de persecución penal, donde las funciones de cada una de las partes intervinientes están claramente definidas.

Argentina tuvo durante años una fuerte tradición inquisitiva, que es lo que el movimiento de reforma, a lo largo de todos estos años, ha pretendido cambiar. Nuestro viejo proceso criminal tenía el objetivo único de averiguar la verdad y el respeto de los derechos de las personas involucradas en el proceso era algo secundario; esclarecer el hecho ha estado por encima de todas las cosas, y la importancia por los derechos humanos ha sido relegada a un segundo plano. En virtud de ese norte, el Estado ignoró todas las garantías establecidas para la protección de las personas en contra del poder estatal, soportando decisiones arbitrarias sin posibilidad alguna de ejercer sus derechos de acuerdo a las líneas básicas de un Estado democrático; concentró las funciones de investigación, acusación y decisión en la misma persona, el juez inquisidor, quien ha sido el encargado tanto de investigar los delitos que a su conocimiento llegaran como de juzgarlos, quitándole a esas decisiones cualquier nota de imparcialidad que pudiera haber tenido; las actuaciones realizadas en el marco del proceso penal han sido prácticamente secretas, imposibilitándose la participación de los ciudadanos en la administración de justicia e ignorándose de esta manera el ejercicio del control por parte de los mismos, que es una pauta esencial en una república democrática; la confesión de la persona perseguida penalmente se ha convertido en el medio de prueba más utilizado, y a través de esa utilización se ha visto vulnerada la presunción de inocencia transformándose en presunción de culpabilidad, el derecho de defensa de la persona perseguida, el derecho a no autoincriminarse en un delito y, del mismo modo, se ha legitimado la práctica de la tortura para conseguir esas confesiones que, en la generalidad de los casos, han sido el único sustento de las acusaciones realizadas por el juez inquisidor. Por último, se olvidó de la víctima y la echó de su conflicto, apropiándoselo, alegando el interés común, o social, realizando una persecución en la que el principal afectado ha pasado a ser uno más de los “auxiliares de la justicia”, que en raras ocasiones ha visto reparado en algo el daño sufrido. El imputado dejó de ser una persona física y pasó a ser un “objeto” de la investigación, que solo 
ha tenido intervención en el procedimiento en cuanto ha servido para cumplir aquel inmaculado fin de “averiguación de la verdad”. Los procesos eran eternos. Y la lista sigue.

El espíritu de las reformas era claramente morigerar, erradicar y cambiar esto. Se intentó comenzar a sentar las bases de otro tipo de Estado; un Estado democrático que respete los derechos de las personas que viven en él, y que lleve ese respeto a la parte más sensible de su poder: el poder de perseguir penalmente a los individuos. Todos los cambios que se han producido en la justicia penal han tendido a concretizar un objetivo principal: la democratización en su administración, estableciendo una distribución equitativa de las funciones en el proceso penal, determinando que en el mismo habrá un juez que tendrá como función la de decidir de acuerdo a las pruebas que las partes involucradas traigan a su conocimiento y la de velar por el respeto de los derechos y garantías de dichos involucrados. De este modo, eliminando la funciones de investigación y acusación de su ámbito de intervención, y poniendo dichas funciones en cabeza del Ministerio Público, se ha logrado garantizar que quienes se vean involucrados en un proceso penal, tendrán la certeza de contar con un juez que decidirá sobre el caso con imparcialidad, libre de los prejuicios que en el modelo anterior de enjuiciamiento le provocaba el hecho de tener a su cargo la investigación. Por otra parte, se intenta también fortalecer las garantías con las que debe realizarse un proceso penal, los derechos de la persona perseguida penalmente, que en realidad rigen desde 1853, solo que a alguien en el camino se le olvidaron.

Otro cambio de fundamental importancia, dentro de lo que es la investigación de los hechos, es el establecimiento claro de que las pruebas no pueden ser nunca obtenidas a través de medios o prácticas ilícitas, y la anulación de las obtenidas a través de dichas prácticas. En el nuevo sistema se pretenden reglas claras en todo lo que significa investigación, que permiten a los operadores involucrados tener la certeza de cuáles son las cosas que pueden hacer, y bajo qué condiciones pueden hacerlas, y cuáles están prohibidas en el marco de la investigación penal.

En cuanto a la persona afectada por el delito, el movimiento de reforma también ha logrado plasmar los derechos que esta persona puede ejercer dentro del proceso penal. Como decíamos más arriba, la víctima ha sido excluida en el marco del procedimiento inquisitivo, y el Estado, que se ha apropiado de su lugar, nunca le ha dado respuestas satisfactorias en cuanto a la resolución del conflicto. Por este motivo es que, las reformas procesales pe- 
nales tienden a darle un mayor protagonismo dentro del proceso, estableciendo que, sin necesidad de cumplir con requisito alguno, la persona afectada tendrá el derecho a ser oída dentro del proceso cuando ella lo considere necesario. Del mismo modo, las nuevas legislaciones establecen una serie de mecanismos que permiten que el afectado por un delito tenga cierta disposición que posibilite la reparación del daño sufrido de una manera más rápida y eficiente. Otro elemento que posibilita ese control, es el establecimiento de un verdadero juicio, oral, público, contradictorio y continuo. El establecimiento de la oralidad como forma de realización de ese juicio, no solo es importante porque permite que ese control por parte de la sociedad sea efectivo, sino que además posibilita que el proceso sea más rápido, dando fin así a aquellos interminables trámites característicos del proceso escrito, en los que la persona nunca tenía una clara idea de cuándo y cómo terminaría su odisea por la administración de justicia.

Finalmente, reconociendo que a través de una lectura errónea del principio de legalidad se ha terminado en una parálisis del sistema judicial, otro de los parámetros de la nueva ideología procesal penal intenta introducir criterios de oportunidad e institutos que tienen más en cuenta la realidad del proceso y no tanto el fin último de averiguar la verdad. Es que el movimiento de reformas reconoce que lo que la Sociedad quiere no es la verdad a cualquier precio y avasallando a los propios integrantes: a las víctimas, que se las olvida, y a los imputados, que se los estigmatiza, la mayor de las veces, innecesariamente, sino que lo que la Sociedad quiere es tener un modelo procesal penal que se ampare en la Constitución y en su espíritu, en una sociedad democrática, en un proceso penal participativo, razonable, equidistante con los conflictos. No se quiere descubrir verdades, sino solucionar conflictos y proveer respuestas a los ciudadanos, que debe ser el fin último del Estado.

\section{Posibilidades de disponibilidad e indisponibilidad}

La preocupación porque el sistema judicial funcione, ha ocupado los últimos treinta años de polémica jurídica, a nivel global. Se trata, como dice Jorge De la Rúa, de

una lucha por el derecho, de lograr, en el marco de la legislación sustantiva, un sistema de aplicación de la misma que genere en la sociedad una verdadera sensación de justicia, de debates y las du- 
das sobre lo justo, lo necesario y lo útil, que se entremezclan para dificultar el logro de eficiencia del sistema. ${ }^{57}$

Pero la realidad se opone a esto y la opinión de la sociedad también sigue siendo adversa.

Se habla de la disponibilidad de la acción cuando el Estado (que es quien detenta el poder de perseguir penalmente a sus habitantes) puede disponer libremente de ella o no ejercitarla en plenitud, aunque se den los requisitos constitucionales y legales. Procesalmente hablando, hay tres alternativas: no promover la acción penal; hacerla cesar una vez que se la promovió o limitarla cuantitativa o cualitativamente, ya sea en su promoción o en su ejercicio. Cuando la acción es indisponible, nada de todo lo dicho ocurre y no puede tocarse la acción penal, por considerarse ello un imperativo categórico constitucional. Debe recordarse que aquí se habla de la puesta en marcha del Estado de los mecanismos tendientes a obtener una sentencia para un caso concreto traído a sus Tribunales, cometido por un sujeto cierto.

En nuestro modelo procesal penal acusatorio-adversarial, y ante la clara realidad que el Estado no puede hacer frente a todos los conflictos judiciales que se le presentan por igual, ya sea por su propia incapacidad fáctica o porque reconoce que no todos esos conflictos tienen la misma identidad, la misma intensidad o representan la misma dañosidad para sus víctimas y para la Sociedad, reconocemos que la acción penal debe ser disponible. De lo contrario, estaríamos atando al Ministerio Público Fiscal, que es el órgano que detenta esa potestad, de pies y manos. Todos los modos que hemos enunciado al hablar de los criterios de oportunidad se identifican claramente con la disponibilidad de la acción y ella se manifiesta claramente ante un archivo, ante una suspensión del proceso a prueba, a través de un avenimiento entre fiscal e imputado o a través de una mediación penal entre víctima, Estado e imputado. Por ello, para no cansar al lector, remitimos a aquellos párrafos.

${ }^{57}$ De La Rúa, Jorge (1996), Disponibilidad de la acción, Academia de Derecho y Ciencias Sociales de la Provincia de Córdoba, publicado en la Revista del Colegio Público de Abogados de Córdoba. 
Códigos Procesales de las provincias de Tucumán, Córdoba, Buenos Aires, Chubut, Chaco y Mendoza. Proyectos de las provincias de Santa Fe, Entre Ríos y Neuquén. Normativa procesal de las provincias de Salta y Jujuy

El espíritu renovador que mencionáramos en el punto anterior se vio reflejado en varios códigos procesales penales provinciales, algunos de los cuales ya hemos venido comentando precedentemente.

\section{Tucumán}

La provincia de Tucumán posee uno de los códigos procesales en materia penal más novedosos. Fue sancionado el 15 de abril de 2010, mediante la Ley 8268, que a su vez modificó la Ley 8240 y que a su vez vino a retocar el primigenio nuevo Código, sancionado mediante la Ley 6203, el 22 de noviembre de 2007. En un proceso que llevó casi tres años, los tucumanos han podido consolidar una norma procesal penal novedosa, que no obstante ha sido criticada desde varios sectores y en varias de sus aristas. ${ }^{58}$

El CPPT ya desde su inicio prevé un sistema donde quien ejerce la acción penal es el Ministerio Público, quien dirige a la policía y quien practica la investigación penal preparatoria (art. 71), poniendo de resalto, con el adjetivo "preparatoria”, que lo que se intenta es centrar el núcleo del proceso en el juicio oral y público, y que lo que hace el Fiscal instructor es reunir las pruebas necesarias para ello. El juez de instrucción solo puede hacer por sí la investigación en casos fundados en privilegios constitucionales (art. 349).

Como segunda nota, el Código prevé la integración al proceso de la víctima (art. 96), del querellante particular, del actor civil, de las personas jurídicas y se consagra la libertad probatoria (art. 193). Además, la libertad del imputado es la regla y solo puede ceder ante la evidencia que el imputado entorpecerá el proceso o se fugará.

Respecto al trámite, se prevé que una vez tomado conocimiento del hecho, el imputado deberá ser intimado del mismo en 24 horas o menos y que luego de

${ }^{58}$ Huici Estrebou, José Luis y Castillo de Ayusa, Ana Lía (1997), Código Procesal Penal de la Provincia de Tucumán. Ley 6203 comentada, anotada y concordada, Ábaco de Rodolfo Depalma, Buenos Aires. 
su declaración debe decidirse si le otorga la libertad o se dispone su prisión preventiva, la que deberá ser excepcional y solo si concurren supuestos taxativamente enumerados (art. 284).

Ya entrando en el área de la IPP, se prevé específicamente un tratamiento para las víctimas de violencia familiar, uno de los males endémicos que viene presentando nuestra Sociedad hace ya varias décadas, al menos en forma pública (art. 304, segundo párrafo).

Asimismo, se prevé un procedimiento especial para casos de flagrancia, donde la investigación debe completarse en un plazo de veinte días desde que se intima del hecho al imputado, prorrogable excepcionalmente por otros veinte días (arts. 317 a 322).

También se receptan soluciones alternativas al juicio, con introducción de criterios de oportunidad, tales como el juicio abreviado (art. 453) y la suspensión del juicio a prueba (art. 321).

\section{Córdoba}

La provincia de Córdoba es señera en el ámbito del derecho procesal y más aun en la específica rama penal, tanto en el primigenio movimiento legislativo de principios del siglo XX y que derivara en la sanción de gran parte de la legislación procesal penal de entonces y asimismo ha tomado la iniciativa en el movimiento de reforma procesal penal que hemos señalado en los puntos anteriores y que vimos se vienen produciendo desde la década del setenta. Muchos de los mejores y más finos procesal penalistas argentinos han nacido en tierras cordobesas.

El Código Procesal Penal cordobés actual (Ley Provincial No 8123), sancionado el 5 de diciembre de 1992 y vigente desde el 16 de enero de 1995, fue el primero en la era moderna de la legislación procesal criminal en Argentina llegó incluso antes que gran parte de la reforma nacional-y fue el primero en cumplir con el mandato constitucional de establecer un sistema de juicio por jurados. Seguidamente, examinaremos algunas de sus notas más salientes, en las que queremos reiterar que fue el primero en legislar en esa dirección. Sabemos lo fácil que es copiar, dado que el verdadero desafío, y allí el acierto de cordobeses y bonaerenses, es innovar, reformar y mejorar. ${ }^{59}$

${ }^{59}$ Para mayor detalle sobre la normativa, ver Cafferata Nores, José I. y Tarditti, Aída (2003), Código Procesal Penal de la Provincia de Córdoba, 2 tomos, Mediterránea, Córdoba. 
Comienza señalando las garantías constitucionales, entre las que destaca el derecho a obtener una sentencia en plazo razonable, y es por ello que ya en Art.1 establece que los procesos penales no pueden durar, normalmente, más de dos años y excepcionalmente, hasta tres.

La acción penal pública se ejerce por el Ministerio Público, quien la dirige, orienta a la policía y se encarga de la investigación penal preparatoria (art. 71). Adhiere claramente al sistema acusatorio y destierra al órgano jurisdiccional como acusador e investigador; el juez debe juzgar y decidir, pues para investigar y acusar está el fiscal.

Establece el Tribunal de Juicio colegiado como derecho del imputado. Así, las cámaras criminales, con salas unipersonales, deben colegiarse si el imputado lo pide o si el propio Tribunal Superior lo considera (art. 34 ter).

En cuanto a los sujetos, abre el abanico y reconoce al fiscal, al juez, al imputado, al querellante particular, al actor civil, al demandado y al citado en garantía y, muy especialmente, a la víctima, quien deberá ser informada de sus derechos y del trámite que se le da al proceso.

Asimismo, rige la libertad probatoria, tanto para probar un hecho como para desestimar la denuncia en el caso contrario. También se erige como principio la libertad personal, la que solo puede ser restringida en muy excepcionales y justificados casos y es el primer código en hablar de "proceso de flagrancia" (art. 275), cuando una persona es sorprendida en plena comisión de un delito.

Ya dentro del esquema de la Investigación Penal Preparatoria, se establece que el imputado debe ser indagado invariablemente dentro de las veinticuatro horas de detenido. El propio código establece que el fiscal puede recibir la declaración del imputado y privarlo de su libertad. Como novedad, establece presupuestos de disponibilidad de la acción, como el archivo de las actuaciones, la suspensión del proceso a prueba, el juicio abreviado, siendo una de las primeras legislaciones en introducir criterios de oportunidad en Argentina. Muy especialmente, en el art. 432, se establece la posibilidad de realizar audiencias de conciliación en sede penal.

Como corolario, destacamos la introducción del juicio por jurados, un derecho del imputado y uno de los aciertos más importantes de este Código, el primero en cumplir con uno de los mandatos democráticos que nuestra Carta Magna lleva más de ciento cincuenta años exigiéndonos. 


\section{Buenos Aires}

La Provincia de Buenos Aires concentra la mayor parte de la población argentina, y por ende, la mayor cantidad de problemas, entre los que el delito no es la excepción. Por ello, debió rápidamente aggiornar su proceso penal a la realidad que le tocaba vivir, en la conciencia que, con el viejo sistema de administración de justicia, el Estado quedaría simplemente paralizado.

Así, se sancionó la Ley 11922 el 1 de enero de 1997 y entró en vigencia el 23 de enero del mismo año, siguiendo los pasos cordobeses. No extenderemos demasiado nuestro análisis sobre esta norma, ya que se ha escrito mucho y muy bueno específicamente sobre ella, por lo que nuestros comentarios siempre quedaran escuetos. ${ }^{60}$ Baste decir que fue y es una norma que en su redacción original era muy buena y que ha sufrido muchos retrocesos, producto de los vaivenes políticos que mencionamos al principio del acápite, pero que también ha avanzado muchísimo. Un ejemplo de ello es la adopción del sistema de mediación penal para resolver conflictos de baja intensidad.

Como notas salientes, se trata de un Código de corte acusatorio, donde el fiscal es quien ejerce y dispone de la acción penal, donde el juez de garantías es quien observa por encima al proceso y controla debidamente el cumplimiento de las garantías y decide sobre las cuestiones que las partes someten a su consideración. Asimismo, prevé el sistema de procesos de flagrancia (debe recordarse que las experiencias de Mar del Plata, Mercedes y San Martín han sido de las primeras, con excelentes profesionales y excelentes resultados en la tramitación de los procesos).

El CPPPBA es hoy un híbrido de proceso acusatorio con ciertos retoques autoritarios, donde hace algunos años, poseía los ya derogados “delitos inexcarcelables”, lo cual chocaba con su espíritu propio, que consagra la libertad como regla y la privación de ella como herramienta muy excepcional (art. 144). ${ }^{61}$ Ejemplos como este muestran cómo una excelente norma en sus oríge-

${ }^{60}$ Ver por ejemplo, Altuve, Carlos Alberto; Chiara Díaz, Carlos Alberto; Domínguez, Federico; Hortel, Eduardo C.; Soria, Pedro L. y Vázquez Rossi, Jorge E. (2005), Código Procesal Penal de la Provincia de Buenos Aires, Rubinzal Culzoni, Santa Fe. Lo interesante de esta obra es que está escrita por varios de los integrantes de la comisión redactora del código, lo que le da valor agregado.

${ }^{61}$ La Ley 12.405, del año 2000, estableció las reformas al régimen excarcelatorio, imponiendo delitos inexcarcelables, los que lograron triplicar en poco tiempo la población carcelaria 
nes puede convertirse en un absurdo jurídico, con graves inconsistencias, merced al oportunismo de ciertos sectores. Se trata de una crítica constructiva, pues creemos que los excelentes procesalistas que trabajaron en él, bien pueden ser replicados y mejorados. No obstante, el espíritu del principio acusatorio, de la separación de funciones, de los criterios de oportunidad, del no enceguecimiento a llevar todo a juicio oral a toda costa y de la participación de la víctima, están intactos.

\section{Chubut, Chaco y Mendoza}

Estas tres provincias poseen ordenamientos rituales criminales actualizados. No obstante, también han tenido algunos cuestionamientos en ciertos procesos de reforma de ellos, pues en los tres casos han sufrido embates, retrocesos y hasta algunas desnaturalizaciones de los institutos que primigeniamente se sancionaron. Incluso Mendoza no ha logrado extender en tiempo razonable la reforma a todo el territorio.

Chubut sancionó la Ley 5478 el 31 de octubre de 2006, y con ella puso en vigencia un nuevo Código Procesal Penal, basado en los principios de oralidad, contradicción, publicidad, concentración, inmediación, simplificación y celeridad. Toda una declaración. Se quiere un proceso penal oral -basado en audiencias, con inmediación de juez y partes y decisión fundada instantánea-, contradictorio -donde las partes, imputado y fiscal, hacen valer sus posturas y el juez decide-, simplificación y celeridad, consagrando la disponibilidad de la acción por parte del fiscal -que es quien la ejerce- a través de la introducción de criterios de oportunidad (archivos tempranos, suspensión del proceso a prueba, juicio abreviado, proceso de flagrancia, mediación penal para conflictos de baja tensión con el bien jurídico).

Si bien en Chubut la libertad del imputado es la regla, quizás la realidad sobrepasó y amilanó al legislador, inducido por la Sala Penal del Superior Tribunal de Justicia provincial, e introdujo al "riesgo de reiteración delictiva” como una de las causales legitimantes del dictado de la prisión preventiva. De hecho

y no aportaron soluciona alguna al problema delictivo bonaerense, pese a que el entonces gobernador hablaba de "meterle bala a los delincuentes". El fallo "verbitsky” de la corte suprema de justicia de la nación, evidenció esta realidad terrible, la que luego tuvo que ser derogada, con el daño ya hecho. 
el dr. José Raúl Heredia, uno de los juristas que participaron en la sanción de la novedosa norma patagónica, dijo

Se han desechado los presupuestos de la peligrosidad del imputado -no procesal-, la repercusión social del hecho y otros semejantes que fueron preferidos en la legislación de facto y recuerdan al famoso motivo de prisión de 'alarma social' (Erregung in der Öffentlichkeit), es decir, permitir acordar la prisión cuando la conducta del imputado o de una persona, del autor en suma, causara alarma, agitación o intranquilidad en la sociedad, introducido por la Novela Procesal Penal nacionalsocialista de 1935. La regla de autorización de la prisión preventiva es la de peligrosidad procesal; ella se erige en un instrumento para garantizar la efectividad de la potestad jurisdiccional - potestad punitiva del Estado- en tanto posibilita que el órgano jurisdiccional adopte determinadas precauciones para asegurar el normal desarrollo del proceso y la efectividad de la eventual sentencia condenatoria. Cabe remitir al artículo 49, C.Ch, en cuanto él dispone que la privación de la libertad solo procede "siempre que existan elementos de convicción suficientes de participación en un hecho ilícito y sea absolutamente indispensable para asegurar la investigación y la actuación de la ley" y al principio del artículo 49, C.Ch: "La privación de la libertad tiene carácter excepcional y solo puede ordenarse en los límites de esta Constitución...”. El Código remite a la Constitución [artículos 1, 20, 212, 213, 220 a 222., CPrPen]. De donde, si no median motivos fundados para temer en el peligro de fuga, de entorpecimiento o que se frustre la aplicación de la ley penal en el caso, pudiendo asegurarse ello por otros medios, no existe razón en principio que justifique constitucionalmente la prisión preventiva. Cuando ésta se expande, como viene sucediendo, además de innumerables problemas de todo tipo, se ocasiona una violación al diseño constitucional del proceso penal [artículos18 y 75 (22), C.N.] erigiéndosela en un anticipo de pena. ${ }^{62}$

${ }^{62}$ Heredia, José Raúl, “Reflexiones a propósito del nuevo Código Procesal Penal de Chubut. Ley 5478, en http://www.acader.unc.edu.ar/artreflexionesnuevocodigoprocesalchubut.pdf. 
Gracias al esfuerzo de muchos de sus redactores y de los operadores judiciales chubutenses, últimamente se ha observado una vuelta al espíritu original del Código, bajándose el número de prisiones preventivas, acelerando notablemente los trámites de juicios, acercando más la administración de Justicia a la víctima y a la Sociedad en sí, reconociendo a la persona sometida a proceso, en lugar de objetivarla como "imputado", y apostando más a criterios de oportunidad.

Con respecto a la provincia del Chaco, sancionó su nuevo Código Procesal Penal el 4 de noviembre de 1998, mediante la Ley 4538 y fue promulgado el 3 de junio de 1999. Si bien puede parecer una norma con cierto recorrido de tiempo, ha sufrido constantes reformas, no permitiéndosele al cuerpo homogéneo asentarse. ${ }^{63}$

Sin perjuicio de ello, la norma chaqueña consagra la libertad personal como regla y la privación de ella solo como excepción, a similitud de las normas que hemos venido reseñando. Aquí también el Ministerio Público detenta la acción penal, la ejerce y dispone de ella, denotando la separación de funciones que el movimiento de reforma se había propuesto. Al igual que en su hermana bonaerense, el órgano judicial es denominado “Juez de garantías”, teniendo la nuclear función de velar por todo el proceso, decidir las cuestiones donde se encuentran afectados derechos fundamentales y escuchar a las partes, en alusión al principio del contradictorio y la inmediatez.

También la norma chaqueña introduce criterios de oportunidad, soluciones alternativas al juicio y hace participar a la víctima de la resolución del caso que la afectó.

Sin perjuicio de ello, también adolece del mismo problema de las provincias de Buenos Aires, Chubut y otras, que es el de la desnaturalización de su espíritu democrático y garantista a través de la limitación a los principios excarcelatorios y la ampliación de las posibilidades de aplicación de prisión preventiva. Otras disposiciones que despiertan polémicas es el plazo de diez días que posee el Fiscal para decidir la situación procesal del imputado, en lugar de las veinticuatro horas taxativas que prevén la mayoría de los códigos del nuevo proceso de reforma. Una de las falencias del Código chaqueño es quizás no poseer un tratamiento diferenciado para los delitos cometidos en flagrancia, algo que sí hacen algunos de los que hemos anotado.

${ }^{63}$ Sin perjuicio de las muy pequeñas consideraciones que vertimos, recomendamos la lectura de Alegre, Juan Ramón (2007), Nuevo Código Procesal Penal de la Provincia del Chaco”, Moglia, Corrientes, quizás la obra más completa sobre esta norma. 
Finalmente, la provincia de Mendoza sancionó su nuevo Código Procesal Penal, mediante la Ley 6730 el 16 de noviembre de 1999, el que continúa vigente. Se trata de un sistema acusatorio, que sufrió luego el embate de más de una quincena de leyes que terminaron trastocando su espíritu. Tiene una presencia importante de criterios de oportunidad, con el establecimiento de la suspensión del juicio a prueba, el juicio abreviado, el procedimiento de flagrancia, la mediación penal y el archivo basado en la insignificancia de la cuestión. Entre lo novedoso, el Código habla de "justicia restaurativa”, dejando en claro que se está ante una norma que pretende, ante todo, restablecer la paz y armonía social.

Entre sus antecedentes - al igual que ocurre con casi todos los mencionados anteriormente- están el Código Procesal Penal costarricense y el Código de procedimientos penales modelo para Iberoamérica. Una de las críticas que quizás se le hacen es que la parte más importante o a la que más se tiende es a la investigación, cuando ello debiera centrarse en la etapa de juicio oral y público, siendo la etapa investigativa una mera preparación o descarte hacia el juicio.

Entre las novedades positivas que el sistema procesal penal mendocino posee está la presencia de fiscales y ayudantes fiscales en todas las comisarías, tomando directo conocimiento de la problemática delictiva, conociendo de primera mano la impresión de la víctima y desplazando a la policía al rol que verdaderamente le cabe, esto es, dar tranquilidad en las calles en lugar de recibir denuncias (algo similar a lo que ocurre en la Ciudad de Buenos Aires, donde se encuentra en pleno auge la creación de Unidades de Orientación y Denuncias, por parte del Ministerio Público, y tendiendo hacia la desjudicialización de la fuerza policial, para otorgarle mayor operatividad).

\section{Santa Fe, Entre Ríos y Neuquén}

La provincia de Santa Fe está en camino de establecer un gran cambio cultural y en materia procesal penal que, si bien tardará algunos años en ser implementado totalmente, ya está comenzado a regir en distintas áreas del proceso. Básicamente, se pretende oralidad, con el fin de lograr tribunales más descongestionados, mayor inmediatez, agilidad y transparencia, quitándole el rol

${ }^{64}$ Para un mejor examen de la normativa, ver la excelente obra de Erbetta, D.; Franceschetti, G. y Orso, T. (2009), Código Procesal Penal de la Provincia de Santa Fe, Rubinzal Culzoni, Santa Fe. 
protagónico al juez durante el proceso en cuanto a la investigación y la fase acusatoria, dándoselo al fiscal, quien desde ahora pasará a tener autonomía. Este proyecto recibió sanción el 31 de agosto de 2007, convirtiéndose en la Ley 12734, ${ }^{64}$ la que, junto a la nueva legislación orgánica del Ministerio Público Fiscal, de la Defensa y del Poder Judicial -estableciendo la separación funcional que exige el nuevo modelo acusatorio-adversarial-, despertó fuertes reticencias en varios frentes, sobre todo bajo los argumentos que modificaba la estructura de la vetusta Constitución Provincial y que disponía de la acción penal, estando ello vedado. ${ }^{65}$ Ahora sí, Santa Fe tiene un proceso penal un poco más justo y a tono con los derechos consagrados por las Constituciones de nuestro país y de Santa Fe y los documentos internacionales incorporados a nuestro ordenamiento jurídico. ${ }^{66}$

Entre Ríos ha logrado consolidar en la conciencia jurídica local su nuevo Código Procesal Penal, sancionado el 20 de diciembre de 2006, a través de la Ley 9754. Así, mediante la Ley 9818, del 24 de noviembre de 2007, se suspendió por un año su vigencia, pues no estaban dadas las condiciones estructurales para que el mismo pudiera implementarse. Dicha suspensión fue prorrogada por la Ley 9884 del 6 de enero de 2009, estableciéndose una puesta en marcha paulatina a través de distintas jurisdicciones que fueran adoptando el nuevo modelo (Concordia, Gualeguay, Paraná y Concepción del Uruguay, en ese orden, culminando este año en la circunscripción Paraná). Y ese que este nuevo ordenamiento procesal penal que pugna por poner en práctica plenamente Entre Ríos es innovador en todos sus aspectos, fundamentalmente, en las conciencias de sus operadores. Incorpora criterios de oportunidad, divide las tareas y funciones clásicas, incorpora y escucha a la víctima, oraliza gran parte del proceso, incorpora a la mediación penal y a los mejores institutos de soluciones alternativas al conflicto penal. ${ }^{67}$

${ }^{65}$ Sobre el particular, mereció un gran espacio en la prensa especializada el debate entre el procurador general Bassó, que peticionaba la inconstitucionalidad de toda la normativa, y la posición de la corte suprema provincial, que terminó avalando el nuevo proceso de reforma penal. Para mayor profundidad en la cuestión ver Finocchiaro, Enzo, "El avance del nuevo proceso penal en santa fe consideraciones sobre el fallo de la suprema corte”, en el suplemento de derecho penal y procesal penal, El Dial, Buenos Aires, 21/09/2010.

${ }^{66}$ Orso, Tomás, “¡Que el juicio sea oral y no leído! el legislador santafesino ya dio su palabra”, en el suplemento de derecho penal y procesal penal, El Dial, Buenos Aires, 21/11/2010.

${ }^{67}$ Para mejor conocimiento del nuevo Código Procesal Penal de Entre Ríos ver Chiara Díaz, C., Erbetta, D., Franceschetti, G. y Orso, T. (2010), Código Procesal Penal de la Provincia de Entre Ríos, Nova Tesis, Rosario. 
En Entre Ríos ocurre en gran medida lo que ha venido ocurriendo en la mayoría de las provincias, donde las conciencias judiciales ya se han "acostumbrado" a un modelo determinado y prefieren no mutar su "tranquilidad" con nuevos modelos que trastocan la Constitución, pervierten varios de los estereotipos y obliga a trabajar más, mejor y con mayor eficiencia, incorporando al "mundo judicial” a operadores desconocidos (asistentes sociales, psicólogos, especialistas en violencia de género, violencia doméstica, centros orientadores de víctimas y de recepción de denuncias, fiscales activos, jueces directores y garantes del proceso, defensores verdaderamente presentes y jueces mejor y más preparados, en virtud de que la inmediatez se los exige).

Neuquén cuenta con un nuevo código procesal penal, donde se evalúa el juicio por jurados con una modalidad novedosa. 